\title{
Regulation of Wnt Signaling by FOX Transcription Factors in Cancer
}

\author{
Stefan Koch ${ }^{1,2} \mathbb{D}$
}

check for

updates

Citation: Koch, S. Regulation of Wnt Signaling by FOX Transcription Factors in Cancer. Cancers 2021, 13, 3446. https://doi.org/10.3390/ cancers13143446

Academic Editor: Masaru Katoh

Received: 16 June 2021

Accepted: 7 July 2021

Published: 9 July 2021

Publisher's Note: MDPI stays neutral with regard to jurisdictional claims in published maps and institutional affiliations.

Copyright: (C) 2021 by the author. Licensee MDPI, Basel, Switzerland. This article is an open access article distributed under the terms and conditions of the Creative Commons Attribution (CC BY) license (https:// creativecommons.org/licenses/by/ $4.0 /)$.
1 Wallenberg Centre for Molecular Medicine (WCMM), Linköping University, 58185 Linköping, Sweden; stefan.koch@liu.se; Tel.: +46-132-829-69

2 Department of Biomedical and Clinical Sciences (BKV), Linköping University, 58185 Linköping, Sweden

Simple Summary: Cancer is caused by a breakdown of cell-to-cell communication, which results in the unrestricted expansion of cells within a tissue. In many cases, tumor growth is maintained by the continuous activation of cell signaling programs that normally drive embryonic development and wound repair. In this review article, I discuss how one of the largest human protein families, namely FOX proteins, controls the activity of the Wnt pathway, a major regulatory signaling cascade in developing organisms and adult stem cells. Evidence suggests that there is considerable crosstalk between FOX proteins and the Wnt pathway, which contributes to cancer initiation and progression. A better understanding of FOX biology may therefore lead to the development of new targeted treatments for many types of cancer.

Abstract: Aberrant activation of the oncogenic Wnt signaling pathway is a hallmark of numerous types of cancer. However, in many cases, it is unclear how a chronically high Wnt signaling tone is maintained in the absence of activating pathway mutations. Forkhead box (FOX) family transcription factors are key regulators of embryonic development and tissue homeostasis, and there is mounting evidence that they act in part by fine-tuning the Wnt signaling output in a tissue-specific and contextdependent manner. Here, I review the diverse ways in which FOX transcription factors interact with the Wnt pathway, and how the ectopic reactivation of FOX proteins may affect Wnt signaling activity in various types of cancer. Many FOX transcription factors are partially functionally redundant and exhibit a highly restricted expression pattern, especially in adults. Thus, precision targeting of individual FOX proteins may lead to safe treatment options for Wnt-dependent cancers.

Keywords: Wnt; forkhead; FOX; beta-catenin; transcription factors

\section{Wnt Signaling in Cancer}

Wnt signaling is one of the fundamental developmental signaling pathways in the animal kingdom. In adult organisms, it functions as a key regulator of stem cell maintenance and proliferation. Consequently, Wnt signaling is indispensable for numerous biological processes ranging from embryogenesis to tissue homeostasis and regeneration.

The basic principles of Wnt signaling are well-understood [1,2] (Figure 1). In the central Wnt pathway, referred to as Wnt/ $\beta$-catenin or canonical Wnt signaling, pathway activity is determined by the abundance of the transcription co-factor $\beta$-catenin. In unstimulated cells, cytosolic $\beta$-catenin is constitutively marked for proteasomal degradation by a multi-protein destruction complex. Upon activation of Frizzled (FZD) family core receptors and Low-density lipoprotein receptor-related protein (LRP) 5/6 co-receptors by secreted Wnt ligands, the destruction complex is inhibited, which allows $\beta$-catenin accumulation. $\beta$-catenin then translocates to the nucleus, where it drives the expression of target genes of Transcription factor/Lymphoid enhancer-binding factor (TCF/LEF) family transcription factors. This gene expression signature, which includes numerous shared as well as tissuespecific gene targets [3], promotes stem cell maintenance, cell cycle progression, and cell proliferation, and is thus essential for organogenesis and tissue homeostasis. Besides 
Wnt/ $\beta$-catenin signaling, there are several non-canonical Wnt pathways that branch off at the receptor level and at the level of the destruction complex [4,5]. In Wnt/Planar cell polarity (PCP) as well as Wnt $/ \mathrm{Ca}^{2+}$ signaling, Wnt ligands engage FZDs and alternative co-receptors to elicit a $\beta$-catenin-independent response. The signaling outcome of these pathways is primarily non-transcriptional, and is best known for regulating cell migration and polarity. Finally, Wnt/Stabilization of proteins (STOP) and Wnt/Target of rapamycin (TOR) signaling promote the stability of proteins other than $\beta$-catenin via the Wnt-induced inhibition of the destruction complex, and support proteome maintenance and cell growth in a transcription-independent manner [4].

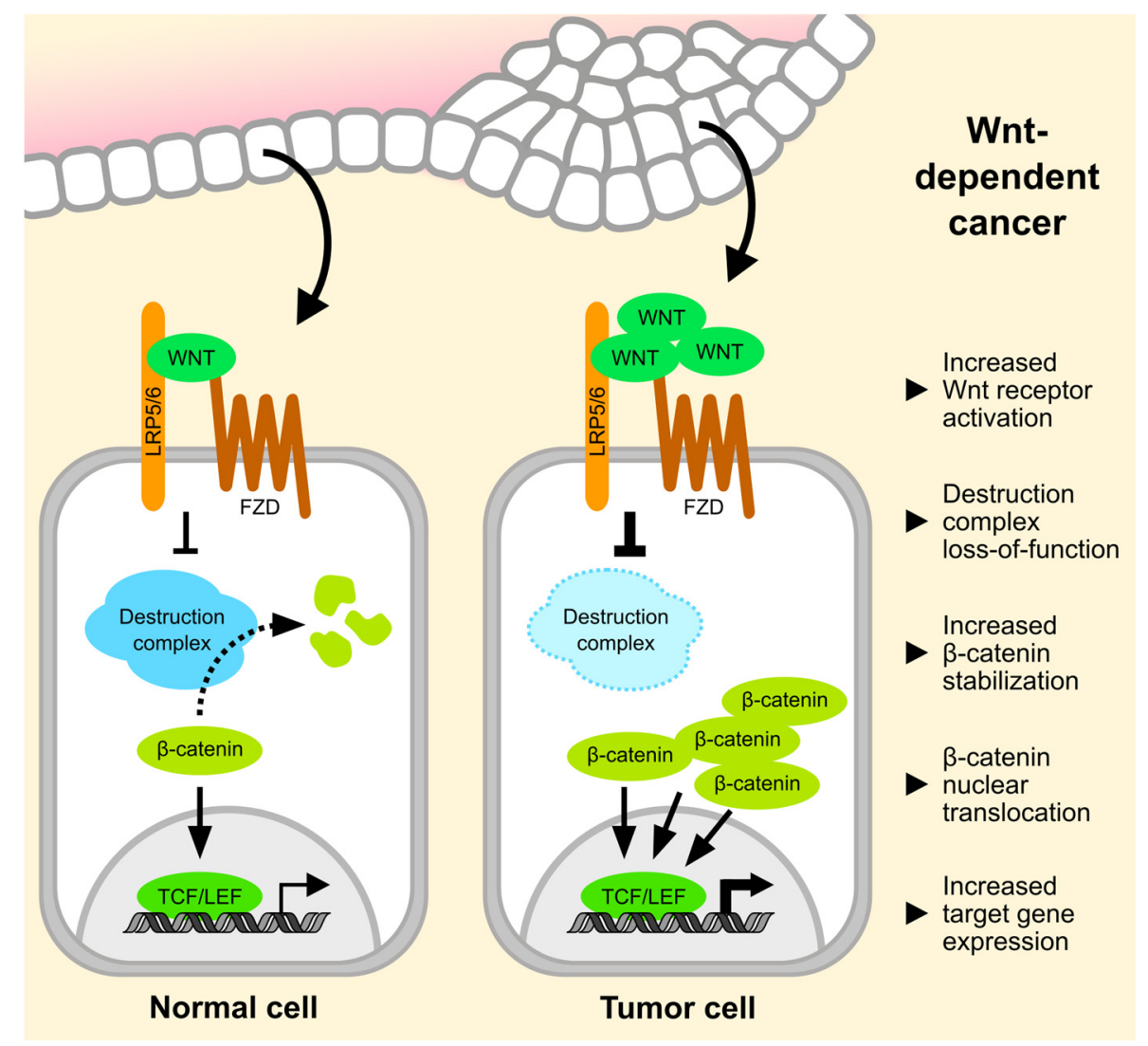

Figure 1. Overview of the canonical Wnt/ $\beta$-catenin signaling pathway. Hallmark alterations in Wnt pathway activity in Wnt-dependent cancer cells are indicated on the right.

Given the prominent roles of Wnt signaling in embryogenesis and stem cell regulation, it is unsurprising that dysregulated Wnt pathway activity is associated with numerous serious disorders, especially cancer [1,6,7]. Indeed, the term Wnt itself references the identification of the first mammalian pathway component (Wnt1, then known as int-1) as an oncogene activated by viral integration [8]. In the more than 30 years following this discovery, $\mathrm{Wnt} / \beta$-catenin signaling in particular has taken center stage as a major oncogenic pathway in various types of cancer. A prime example for Wnt-dependent cancer is sporadic colorectal cancer (CRC). The vast majority of tumors in CRC patients have activating mutations in Wnt pathway components, of which most result in loss-of-function of the destruction complex or the aberrant stabilization of $\beta$-catenin [9]. Additionally, elevated Wnt ligand levels increase pathway activity in CRC irrespective of underlying mutations [10]. Chronic Wnt pathway activation in colonic epithelial cells leads to the formation of hyper-proliferative adenomas, which are hotspots for mutations in other genes involved in cancer initiation and progression. Evidence from mouse models of CRC suggests that restoration of normal Wnt activity is sufficient to induce complete tumor regression even in fully transformed colon cancer [11], which highlights the importance 
of sustained Wnt signaling not only in tumor development, but also cancer stem cell maintenance. Wnt pathway mutations are common in other types of cancer as well, although they occur at a lower frequency compared to CRC. For example, one in four hepatocellular carcinomas and uterine corpus endometrial carcinomas exhibit stabilizing $\beta$-catenin mutations, while destruction complex mutations are frequently observed in cutaneous melanomas and gastric adenocarcinomas [6]. Wnt pathway mutations are relatively rare in other cancers, including pancreatic and prostate cancer. Nonetheless, Wnt signaling activity is increased in many of these tumors, which is presumably caused by expression changes in pathway components such as Wnt ligands and receptors [12,13].

Apart from tumor initiation, Wnt signaling also contributes to cancer metastasis [7,14]. A hallmark of advanced carcinomas is epithelial-to-mesenchymal transition (EMT), which enables cancer cells to leave the main tumor and spread to different locations in the body. Several key regulators of EMT are Wnt/ $\beta$-catenin target genes, including the zinc finger proteins SNAI1 and SNAI2 that repress epithelial cell adhesion molecules $[15,16]$. Wnt signaling additionally stabilizes SNAI1/2 protein through Wnt/STOP $[17,18]$, resulting in rapid EMT following Wnt pathway activation. Wnt/PCP and Wnt/Ca ${ }^{2+}$ signaling promote metastasis as well, by increasing tumor cell migration and invasion $[19,20]$. In particular, altered expression of WNT5A and WNT11, which predominantly activate non-canonical Wnt pathways, has been linked to metastasis in various cancers [12,20]. Wnt signaling has additional roles in tumor progression and treatment resistance, but these are less well understood.

In light of these findings, it is obvious that the Wnt signaling pathway is a priority target for therapeutic intervention in cancer, and clinical trials are currently underway to assess the efficacy of Wnt modulators in several types of cancer [21,22]. However, owing to the pervasive functions of Wnt signaling in normal tissue homeostasis, it remains a considerable challenge to minimize the on-target toxicity of these drugs especially in the intestinal epithelium and the hematopoietic system [23]. It is therefore a major goal in preclinical Wnt research to identify context-dependent pathway regulators that can be safely targeted in human diseases.

\section{Regulation of $\beta$-catenin-dependent Gene Transcription}

Although the basics of Wnt signaling are well-established, it is considerably less well understood how specific Wnt pathway outputs are generated in different tissues and cell types. For example, whether Wnt signaling elicits canonical or non-canonical downstream effects is mostly determined by the interaction of 19 different Wnt ligands with 10 FZD receptors in humans, but few studies have explored the signaling outcomes of individual ligand/receptor combinations [24-27]. Similarly, it is poorly understood how tissue-specific target genes can be selectively induced by the $\beta$-catenin transcriptional complex. Mounting evidence suggests that a wide array of transcription co-factors fine-tunes Wnt target gene expression [28-30], but as Söderholm and Cantù pointed out, the identity and function of such transcriptional regulators has received relatively little attention in the field [31].

The current paradigm in $\beta$-catenin-dependent gene transcription is that the four TCF/LEF family transcription factors (TCF7, TCF7L1, TCF7L2, and LEF1) constitutively occupy Wnt-responsive DNA elements, and that they are kept in an inactive state by Transducin-like enhancer (TLE) family repressors. Upon Wnt pathway activation, $\beta$ catenin binds to TCF/LEF and inactivates TLE, thereby enabling target gene transcription [32]. Selective gene expression is then achieved by the differential action of the four TCF/LEF transcription factors, which have overlapping but non-identical functions and target genes [33-35]. However, it is unlikely that this mechanism alone explains the different Wnt transcriptional signatures that have been observed even in developmentally related tissues [3].

Besides TLE, numerous other proteins engage $\beta$-catenin and TCF/LEF to stratify the Wnt transcriptional response [28,31]. These interactors include numerous transcription factors that modulate $\beta$-catenin activity and Wnt target gene expression. In the prostate, hor- 
monal activation of the androgen receptor (AR) induces its nuclear translocation, where it competes with TCF/LEF for $\beta$-catenin binding. This results in the concomitant inhibition of Wnt signaling and activation of AR signaling, which has important implications for prostate development and cancer [36,37]. Similarly, the pluripotency factor POU domain class 5 transcription factor 1 (POU5F1) sequesters $\beta$-catenin in the nucleus of stem cells, which simultaneously inhibits Wnt signaling and induces POU5F1 target gene expression, thereby preventing cell differentiation $[38,39]$. Conversely, the inflammatory effector protein AP-1 associates with the $\beta$-catenin transcriptional complex to activate both AP-1 and Wnt target gene expression, which drives the progression of CRC [40-42]. The forelimbspecific T-box transcription factor 3 (TBX3) also activates Wnt signaling by associating with the $\beta$-catenin transcriptional complex, and its aberrant expression may contribute to CRC metastasis [43]. Moreover, transcription factors can regulate Wnt signaling activity by other means. In addition to its ability to bind to and compete for $\beta$-catenin [44], the SRY-Box transcription factor 9 (SOX9) destabilizes $\beta$-catenin via the nuclear translocation of the destruction complex and induction of Mastermind-like protein 2 (MAML2) [45,46], and it induces the expression of Wnt pathway components [47].

\section{Forkhead Box Family Transcription Factors}

The aforementioned examples provide a brief glimpse at the complexity of Wnt signaling at the transcriptional level, and illustrate how tissue and cell-specific Wnt activity is controlled by the action of non-TCF/LEF transcription factors. Below, I review how Wnt signaling is shaped by one of the largest mammalian transcription factor families, the forkhead box (FOX) transcription factors.

FOX proteins are highly conserved transcription factors with 44 family members in humans, not counting five duplicated FOXD4-like genes and the FOXO3 variant FOXO3B [48,49]. They are further subdivided into 19 classes (A through S) based on sequence similarity of their eponymous, DNA-binding forkhead domain. FOX transcription factors are involved in virtually all facets of mammalian biology, including embryogenesis and tissue homeostasis. Accordingly, dysfunction of FOX proteins is associated with severe developmental disorders, autoimmune diseases, and cancer [49-52]. The forkhead domain has undergone relatively little change during evolution from early metazoan ancestors, and most FOX family members bind to similar DNA motifs with differing affinity [53-55]. In contrast, the protein sequences flanking the DNA-binding domain have diverged considerably, and it is generally thought that the specific functions of individual FOX transcription factors are conferred by their interaction with other proteins via these unique regions [50,52]. Consistently, proteomics analyses of 33 FOX family members uncovered distinct sets of interactors for each molecule [56], and functional studies from our group revealed that even closely related FOX proteins can have remarkably different transcriptional activity [57]. Although some FOX transcription factors are expressed near-ubiquitously, most family members exhibit a strongly spatially or temporally restricted expression pattern [49]. For example, FOXE1 is expressed almost exclusively in the thyroid gland, and accordingly, its dysfunction is associated with severe thyroid abnormalities and thyroid cancer [58,59]. Other FOX transcription factors such as FOXB1 and FOXI3 are critical for embryonic development [50], but they are essentially not expressed in adults. Additionally, unlike TCF/LEF transcription factors, FOX proteins are not restricted to any specific signaling pathway, but rather function as downstream effectors in various signaling networks [49].

\subsection{FOX Transcription Factors Are Wnt Pathway Regulators}

Given these considerations, it is not surprising that FOX transcription factors also act as regulators of Wnt signaling. At the time of writing, approximately half of all mammalian FOX transcription factors have been assigned a role in the Wnt pathway, primarily in cancer cells (Table 1). Moreover, in a screening experiment including additional FOX proteins, our group observed that most of them acted as Wnt activators or inhibitors in normal and cancer cells [60]. It appears that the role of FOX proteins in cancer is consistent 
with their function in the Wnt pathway; that is, FOX proteins that work as Wnt pathway activators generally promote tumorigenesis and are induced in cancers, whereas FOX family members that inhibit Wnt signaling are frequently recognized as tumor suppressors and exhibit decreased expression (Table 1, Figure 2). To what extent the contribution of FOX transcription factors to cancer initiation and progression can be explained by their activity in the Wnt pathway is unclear, and will have to be determined on a case-by-case basis. Nonetheless, it is worthwhile to review how FOX transcription factors can modulate Wnt signaling, considering the importance of dysregulated Wnt signaling in cancer biology.

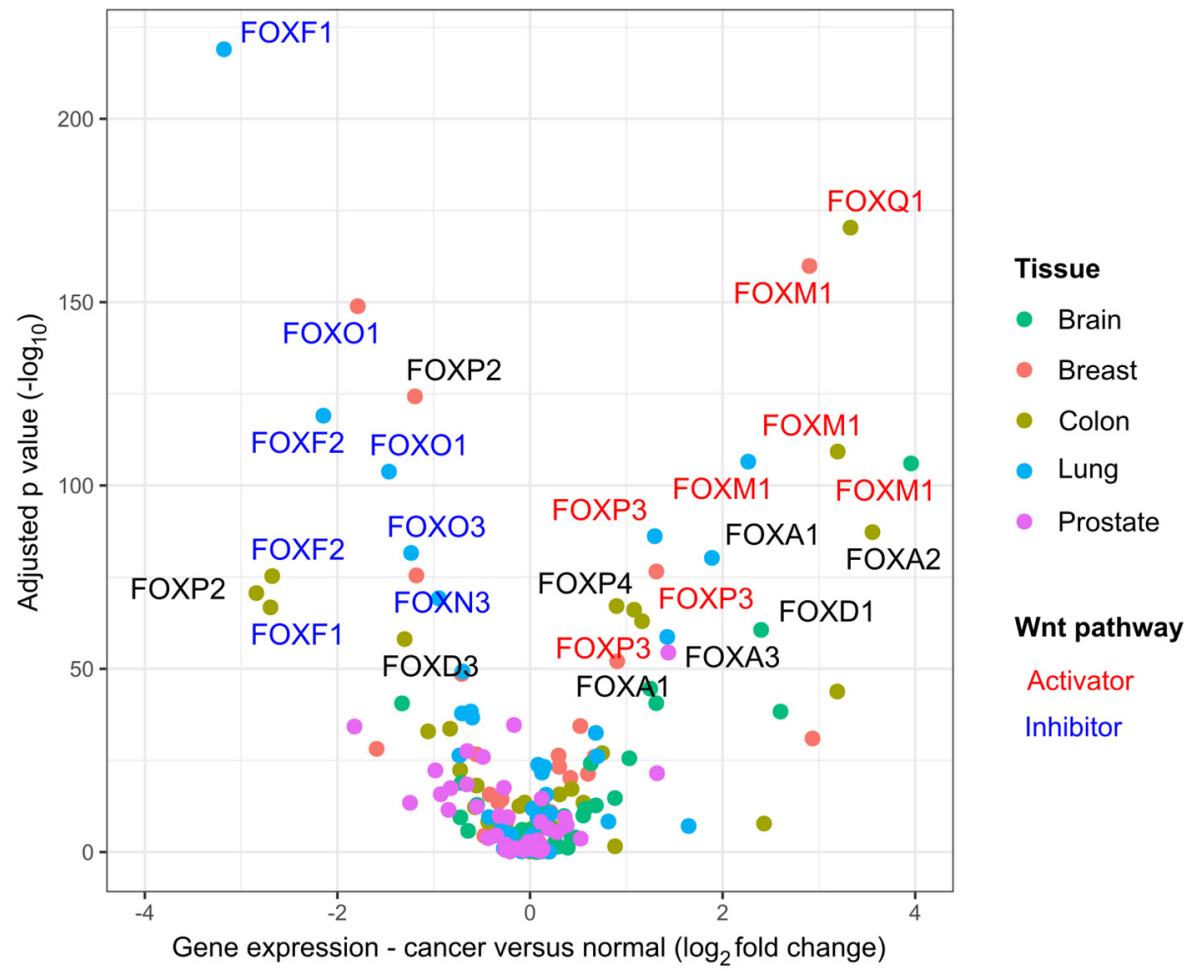

Figure 2. Gene expression changes of FOX transcription factors in selected cancers. Data sources are indicated in the data availability statement at the end of the manuscript. Classification of genes as Wnt pathway activators or inhibitors is based on the literature, see Table 1. Only data points with $>2$-fold change in expression and an adjusted $p$ value $<10^{-50}$ are labeled. 
Table 1. Overview of FOX transcription factors linked to both cancer biology and Wnt signaling.

\begin{tabular}{|c|c|c|c|}
\hline FOX & Relevance for Cancer Biology & Proposed Function in Wnt Signaling & Refs. \\
\hline \multicolumn{4}{|c|}{ Wnt pathway activators } \\
\hline FOXB2 & Putative oncogene in prostate cancer & Induces various Wnt ligands & [60] \\
\hline FOXC1 & $\begin{array}{l}\text { Increases proliferation and metastasis in many } \\
\text { cancer types }\end{array}$ & $\begin{array}{c}\text { Induces CTNNB1 }{ }^{1} \text { and WNT5A; represses Wnt } \\
\text { inhibitor DKK1 }\end{array}$ & [61-63] \\
\hline FOXC2 & $\begin{array}{l}\text { Increases proliferation and metastasis in many } \\
\text { cancer types }\end{array}$ & Induces WNT4 & [64] \\
\hline FOXE1 & Mutation associated with thyroid cancer & May induce WNT5A & [65] \\
\hline FOXG1 & $\begin{array}{l}\text { Associated with cancer progression in glioma } \\
\text { and hepatocellular carcinoma }\end{array}$ & $\begin{array}{c}\text { Binds and stabilizes } \beta \text {-catenin; promotes TCF7L2 } \\
\text { activity; inhibits Wnt ligand expression during } \\
\text { development }\end{array}$ & {$[66,67]$} \\
\hline FOXH1 & $\begin{array}{c}\text { Drives cell proliferation in acute myeloid } \\
\text { leukemia }\end{array}$ & $\begin{array}{l}\text { Synergizes with } \beta \text {-catenin in target gene } \\
\text { expression; may induce CTNNB1 }\end{array}$ & {$[68,69]$} \\
\hline FOXJ1 & $\begin{array}{c}\text { Associated with tumor progression in many } \\
\text { cancer types }\end{array}$ & May stabilize $\beta$-catenin via inhibition of APC & [70] \\
\hline FOXK1 & $\begin{array}{l}\text { Increases proliferation and metastasis in many } \\
\text { cancer types }\end{array}$ & $\begin{array}{l}\text { Promotes nuclear translocation of Wnt scaffold } \\
\text { protein DVL }\end{array}$ & [71] \\
\hline FOXK2 & $\begin{array}{l}\text { Context-dependent oncogene or tumor } \\
\text { suppressor }\end{array}$ & $\begin{array}{l}\text { Promotes nuclear translocation of Wnt scaffold } \\
\text { protein DVL }\end{array}$ & [71] \\
\hline FOXM1 & Major oncogene in many cancer types & $\begin{array}{l}\text { Promotes } \beta \text {-catenin nuclear translocation; } \\
\text { stabilizes } \beta \text {-catenin/TCF7L2 interaction; } \\
\text { synergizes in target gene expression }\end{array}$ & {$[72,73]$} \\
\hline FOXP1 & $\begin{array}{l}\text { Context-dependent oncogene or tumor } \\
\text { suppressor }\end{array}$ & $\begin{array}{l}\text { Activates } \beta \text {-catenin via CBP-dependent } \\
\text { acetylation; synergizes in target gene expression }\end{array}$ & [74] \\
\hline FOXP3 & $\begin{array}{l}\text { Context-dependent oncogene or tumor } \\
\text { suppressor }\end{array}$ & $\begin{array}{l}\text { Synergizes with } \beta \text {-catenin/TCF7L2 in target } \\
\text { gene expression }\end{array}$ & [75] \\
\hline FOXQ1 & $\begin{array}{l}\text { Promotes metastasis in carcinomas; tumor } \\
\text { suppressor in melanomas }\end{array}$ & $\begin{array}{l}\text { Induces Wnt ligands; may promote } \beta \text {-catenin } \\
\text { nuclear translocation via annexin } \mathrm{A} 2\end{array}$ & {$[76,77]$} \\
\hline FOXR2 & Oncogene in many cancer types & Unclear & [78] \\
\hline \multicolumn{4}{|c|}{ Wnt pathway inhibitors } \\
\hline FOXF1 & $\begin{array}{l}\text { Context-dependent oncogene or tumor } \\
\text { suppressor }\end{array}$ & May inhibit WNT5A & [79] \\
\hline FOXF2 & Tumor suppressor in gastric and cervical cancer & $\begin{array}{l}\text { May inhibit WNT5A and induce Wnt inhibitor } \\
\text { SFRP1; promotes } \beta \text {-catenin degradation }\end{array}$ & [79-81] \\
\hline FOXL1 & Tumor suppressor in multiple types of cancer & May reduce proteoglycan co-receptor levels & [82] \\
\hline FOXN3 & $\begin{array}{l}\text { Inhibits proliferation and migration in multiple } \\
\text { types of cancer }\end{array}$ & Inhibits $\beta$-catenin/TCF7L2 interaction & [83] \\
\hline FOXO1 & Tumor suppressor in multiple types of cancer & $\begin{array}{l}\text { Inhibits } \beta \text {-catenin/TCF7L2 interaction, possibly } \\
\text { via LINC01197 }\end{array}$ & [84] \\
\hline FOXO3 & Tumor suppressor in multiple types of cancer & $\begin{array}{l}\text { Inhibits } \beta \text {-catenin/TCF7L2 interaction by } \\
\text { competitive binding }\end{array}$ & {$[85,86]$} \\
\hline FOXO4 & Tumor suppressor in multiple types of cancer & $\begin{array}{l}\text { Inhibits } \beta \text {-catenin/TCF7L2 interaction by } \\
\text { competitive binding }\end{array}$ & [85] \\
\hline FOXS1 & $\begin{array}{l}\text { Putative tumor suppressor in breast cancer and } \\
\text { hepatocellular carcinoma }\end{array}$ & May inhibit CTNNB1 expression & [87] \\
\hline
\end{tabular}




\subsubsection{Regulation of $\beta$-catenin Localization and Stability}

$\beta$-catenin stabilization and nuclear translocation are central events in canonical Wnt signaling [1]. Thus, any molecule that affects the protein level or subcellular localization of $\beta$-catenin directly controls the magnitude of the Wnt transcriptional response. Several FOX family members are known to regulate $\beta$-catenin in this manner, most prominently the major oncogene FOXM1. FOXM1 is overexpressed in many types of cancer and contributes to all cancer hallmarks, including increased proliferation, reduced apoptosis, tumor metastasis, and drug resistance [88-90]. FOXM1 exerts its oncogenic functions through transcriptional as well as non-transcriptional modes of action, which include its interaction with protein partners such as $\beta$-catenin $[88,91]$. Zhang et al. showed that FOXM1 binds $\beta$-catenin in normal and cancer cells, and that the Wnt transcriptional activity in different cells correlates with FOXM1 abundance [73]. FOXM1 strongly enhances the nuclear translocation of $\beta$-catenin, which is required for the tumor-initiating capacity of glioblastoma cells in vivo (Figure 3a). Subsequent studies confirmed these observations in other cancers such as meningiomas and pancreatic tumors [92,93], suggesting that the nuclear shuttling of $\beta$-catenin by FOXM1 is a common pathomechanism in cancer.
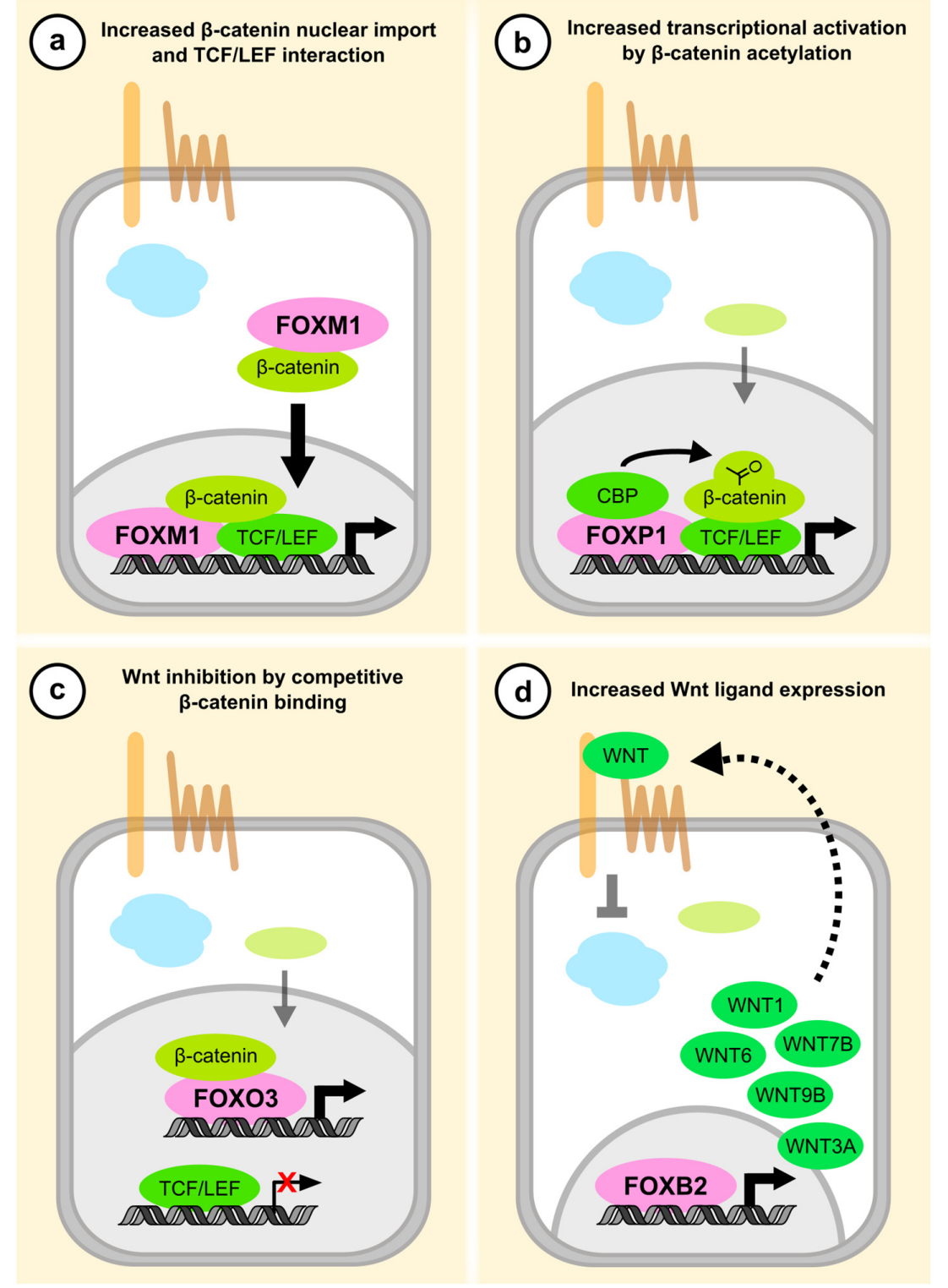

Figure 3. Proposed mode of action of selected FOX transcription factors in the Wnt signaling pathway. 
Other FOX family members have been implicated in $\beta$-catenin stabilization and nuclear import as well. Overexpression of FOXG1 is associated with apoptosis resistance and metastasis in various cancers $[94,95]$. FOXG1 directly interacts with $\beta$-catenin, and depletion of FOXG1 reduced nuclear $\beta$-catenin abundance in hepatocellular carcinoma (HCC) cell lines [67]. Consistently, expression of FOXG1 is strongly positively correlated with nuclear $\beta$-catenin levels in HCC patient samples. Similarly, Liu et al. reported that FOXJ1 increases nuclear $\beta$-catenin levels in CRC cell lines, which the authors attributed to a reduction of truncated (i.e., tumor-initiating) APC in these cells [70]. It is unclear how FOXJ1 could control the abundance of mutant APC, and it should be noted that FOXJ1 is more commonly associated with cancers in which APC mutations are infrequent [96,97]. Finally, FOXQ1 depletion inhibits $\beta$-catenin nuclear translocation without affecting $\beta$-catenin protein levels in CRC cell lines [98]. FOXQ1 may promote $\beta$-catenin nuclear import indirectly via induction of annexin A2 [77], but FOXQ1 also physically interacts with $\beta$-catenin in cancer cells [76]. Overexpression of FOXQ1 has been linked to EMT and tumor metastasis in various cancers [99], and thus it is of interest to determine its molecular functions. However, the precise mode by which FOXQ1 and FOXJ1 activate Wnt signaling, and whether this function is relevant for their role in cancer biology, requires further investigation.

Conversely, other FOX transcription factors may inhibit Wnt signaling by destabilizing $\beta$-catenin. Higashimori et al. reported that FOXF2 induces the expression of the E3 ubiquitin ligase IRF2BPL in gastric cancer cell lines [80]. IRF2BPL associates with $\beta$-catenin and causes its proteasomal degradation independently of the destruction complex. Consistently, FOXF2 inhibited the growth of gastric tumor cells in vivo, and epigenetic silencing of FOXF2 is associated with poor prognosis in stomach cancer patients. FOXF2 additionally induces Secreted frizzled-related protein 1 (SFRP1) in intestinal fibroblasts [81]. SFRP family proteins function as soluble decoy receptors for Wnt ligands [100], and destabilize $\beta$-catenin by increasing the activity of the destruction complex. Thus, it is likely that FOXF2 attenuates Wnt signaling via the transcriptional regulation of multiple $\beta$-catenin inhibitors.

\subsubsection{Regulation of the Wnt Transcriptional Complex}

Non-TCF/LEF transcription factors shape specific Wnt signaling outputs by engaging the Wnt transcriptional complex [31], and several studies have shown that this is the case for FOX transcription factors as well. Aside from its role in $\beta$-catenin shuttling, FOXM1 reinforces Wnt target gene expression at the chromatin level. Zhang et al. reported that FOXM1 is required for the efficient recruitment of $\beta$-catenin to TCF7L2 at Wnt-responsive DNA elements, and thereby increases Wnt target gene transcription [73]. In a followup study, the same group showed that FOXM1 facilitates $\beta$-catenin/TCF interaction by protecting $\beta$-catenin from Beta-catenin-interacting protein 1 (CTNNBIP1)-mediated inhibition [72]. CTNNBIP1 is a ubiquitously expressed protein that blocks TCF activation by competitive binding to $\beta$-catenin [101]. FOXM1 interacts with the same $\beta$-catenin domain as CTNNBIP1, and thereby de-represses $\beta$-catenin/TCF association [72,73].

A different mode of action has been described for FOXP1, which has contrasting functions in various types of cancer [102]. In lymphomas, where its overexpression is associated with poor prognosis, FOXP1 increases Wnt/ $\beta$-catenin signaling following upstream pathway activation [74]. Walker et al. observed that FOXP1 interacts with $\beta$-catenin, TCF7L2, and the acetyl transferase CREB-binding protein (CBP) at TCF binding sites, and that it facilitates the CBP-dependent acetylation of $\beta$-catenin (Figure $3 b$ ). $\beta$-catenin acetylation is an activating post-translational modification that increases the induction of a subset of Wnt target genes [103]. Consistently, FOXP1 was unable to promote Wnt-dependent transcription when the CBP acetylation site on $\beta$-catenin was deleted [74]. In their initial screening experiments, Walker et al. also identified the closely related FOXP4 as a potential Wnt activator, but this observation was not explored further. While it thus remains to be tested if FOXP4 controls Wnt signaling as well, a separate study revealed that FOXP3 increases Wnt activity in non-small cell lung cancer (NSCLC) [75]. Yang et al. showed that FOXP3 interacts with $\beta$-catenin and TCF7L2, and that FOXP3 overexpression 
increased $\beta$-catenin/TCF association and Wnt target gene expression, similar to FOXP1. Accordingly, FOXP3 gain-of-function increased tumor growth and metastasis of NSCLC cell lines in vivo [75]. FOXP2 was also recently found to engage $\beta$-catenin and regulate the expression of several target genes [104], but the functional relevance of this interaction was not investigated in this study. Collectively, these observations suggest that all class $P$ FOX proteins act as Wnt pathway activators. It remains to be determined if this function involves a shared molecular mechanism, such as the promotion of $\beta$-catenin acetylation.

FOXG1 enhances Wnt signaling at the chromatin level as well. As with FOXM1 and FOXP1, FOXG1 binds TCF7L2 in addition to $\beta$-catenin, and depletion of FOXG1 decreased the recruitment of $\beta$-catenin to TCF binding sites in HCC cell lines [67]. The authors of this study did not investigate how FOXG1 promotes $\beta$-catenin/TCF interaction, but it has been shown that FOXG1 binds to a different region of $\beta$-catenin than FOXM1 and CTNNBIP1 $[67,73]$. It therefore appears likely that FOXG1 has a distinct mode of action in Wnt transcriptional activation. Finally, FOXH1 promotes the transcription of $\beta$-catenin target genes during early Xenopus development [68]. Afouda et al. observed that a substantial number of genomic loci were co-occupied by $\beta$-catenin and FOXH1 in zygotes. Accordingly, FOXH1 depletion in blastula stage Xenopus embryos reduced the expression of maternal Wnt target genes, but this was not associated with altered recruitment of $\beta$-catenin to TCF binding sites. Thus, the cooperative action of $\beta$-catenin/TCF and FOXH1 transcriptional complexes may be required for the induction of specific Wnt targets, at least during embryonic development.

On the other hand, some FOX transcription factors compete with TCF/LEF for $\beta$ catenin binding, and act as inhibitors of canonical Wnt signaling. FOXO3 and FOXO4 engage $\beta$-catenin via the same domains as TCF/LEF, and thereby inhibit Wnt transcriptional activity while at the same time increasing the expression of FOXO target genes (Figure 3c) [85,105-107]. Unlike most other FOX proteins, the nuclear localization and activity of class O FOX transcription factors is regulated by post-translational modification upon growth factor signaling and oxidative stress [108]. Accordingly, $\beta$-catenin was shown to be required for FOXO-dependent stress response and longevity in nematodes [106]. Although these earlier studies focused on cell stress, the reciprocal regulation of Wnt signaling and FOXO-dependent gene transcription is important for cancer biology as well. For example, FOXO3 engages $\beta$-catenin and decreases $\beta$-catenin/TCF7L2 interaction in prostate cancer cell lines [86]. Liu et al. reported that depletion of FOXO3 induced cancer cell migration, invasion, and EMT, which was blocked by concomitant $\beta$-catenin loss-of-function. In other types of cancer, $\beta$-catenin may subvert the role of FOXO3 as a tumor suppressor. Induction of FOXO target genes results in cell cycle arrest and apoptosis, which is inhibited by activating mutations in the Phosphoinositide 3-kinase/Protein kinase B (PI3K/PKB) pathway that sequester FOXO in the cytosol [109]. Several clinically used PI3K/PKB inhibitors promote FOXO nuclear translocation, thereby restoring its tumor suppressor function. However, Tenbaum et al. showed that the treatment outcome of these drugs in CRC depends on the abundance of $\beta$-catenin [110]. In tumor cells with low $\beta$-catenin levels, FOXO3 nuclear translocation caused by PKB inhibitor treatment induced apoptosis and reduced tumor growth in vivo. In cells with high nuclear $\beta$-catenin levels, however, PKB inhibition had no effect on cancer cell proliferation, but rather resulted in tumor metastasis. The authors observed that $\beta$-catenin activates the expression of specific FOXO3 target genes that are thought to drive cell junction disassembly and migration [110]. Thus, competitive binding of FOXO3 to $\beta$-catenin may switch CRC cells from Wnt-dependent proliferation to FOXO-mediated EMT, ultimately causing tumor cell dissemination. Whether these effects are specific for FOXO3 is unclear at this point, but there is some indication that individual FOXO proteins have distinct $\beta$-catenin-dependent target genes. Doumpas et al. reported that activation of $\beta$-catenin in cells lacking all four TCF/LEF transcription factors results in the differential expression of dozens of target genes that are presumably regulated by other transcription factors [111]. The authors identified FOXO4 as one of these alternative transcription factors, whereas FOXO3 had no effect on gene regulation in the absence of 
TCF/LEF. Interestingly, FOXO1 disrupts $\beta$-catenin/TCF7L2 interaction and inhibits Wnt signaling in pancreatic adenocarcinoma cell lines, but in contrast to $\mathrm{FOXO} / 4$, this could be an indirect effect [84]. Ling et al. reported that FOXO1 induces the long non-coding RNA LINC01197, which binds and inhibits $\beta$-catenin. Consistently, LINC01197 overexpression inhibited tumor growth in vivo, and low expression of this RNA was associated with shorter survival in pancreatic cancer patients.

Lastly, FOXN3, a known tumor suppressor in various types of cancer [112], also inhibits Wnt signaling by competitive binding of $\beta$-catenin. Similarly to FOXO3/4, FOXN3 overexpression decreases $\beta$-catenin/TCF7L2 interaction in CRC cell lines, and depletion of FOXN3 increased tumor growth and metastasis in mice [83]. Collectively, these observations suggest that engagement of the Wnt transcriptional complex is a common mechanism by which FOX proteins regulate Wnt signaling in a context-dependent manner.

\subsubsection{Regulation of Wnt Ligand Expression}

Another way in which FOX proteins control Wnt signaling is via the transcriptional regulation of Wnt ligands. Induction of Wnt ligand expression has been linked to disease progression in various cancers, such as ovarian, prostate, and lung cancer [113-115]. It has been suggested that Wnt pathway activation occurs via the de-repression of Wnt ligand transcription [116], or the epigenetic silencing of secreted Wnt inhibitors such as Dickkopfrelated protein 1 (DKK1) and SFRPs [117]. However, it is likely that aberrant transcription factor activity contributes to elevated Wnt ligand levels in cancer. Our group observed that FOXB2, whose expression is normally restricted to the embryonic brain [118], is reexpressed in aggressive prostate cancer subtypes [60]. We found that FOXB2 does not engage $\beta$-catenin, but rather activates Wnt signaling via the induction of multiple Wnt ligands (Figure 3d). Inhibition of WNT7B signaling was sufficient to block the effect of FOXB2, and loss-of-function of FOXB2 reduced Wnt transcriptional activity in prostate cancer cell lines. Accordingly, a FOXB2/WNT7B gene expression signature was associated with poor prognosis in prostate cancer patient data. Although our investigation focused on WNT7B, we observed that FOXB2 significantly increased the expression of 14 out of the 19 human Wnt ligands across multiple cell lines. This suggests that FOX transcription factors might work as universal regulators of Wnt ligand expression. In agreement with this hypothesis, FOXQ1 was found to induce the expression of at least three canonical Wnt ligands in mesenchymal stem cells, namely WNT1, WNT3, and WNT7A [77], which are also controlled by FOXB2 [60]. To what extent these ligands contribute to the activity of FOXQ1 in Wnt/ $\beta$-catenin signaling and cancer biology is unknown, but it is feasible that they amplify the effect on $\beta$-catenin nuclear translocation and thereby increase the oncogenic potential of FOXQ1 [76,77].

Other studies have reported the regulation of individual Wnt ligands by FOX transcription factors. FOXC2, a known oncogene in several types of cancer [119], induces WNT4 in myoblast cell lines [64]. Gozo et al. reported that FOXC2 activates Wnt/ $\beta$-catenin and Wnt/PCP signaling via WNT4, which was required for the inhibition of myoblast differentiation. Concomitant overexpression of both FOXC2 and WNT4 has been observed in some cancers, including CRC [120,121], suggesting FOXC2-mediated induction of WNT4 in tumor cells as well. The other class C FOX protein, FOXC1, also regulates Wnt ligand expression. Han et al. observed that FOXC1 induces the expression of WNT5A in triplenegative breast cancer (TNBC) cell lines, and that WNT5A mediates the FOXC1-dependent effects on cancer cell migration and invasion, but not cell proliferation [62]. The authors further determined that WNT5A induces Matrilysin (MMP7) through a non-canonical Nuclear factor (NF)- $\mathrm{KB}$ signaling pathway, which drives tumor metastasis in mice.

Additional FOX proteins may regulate WNT5A expression. Ma et al. reported that protein levels of FOXE1 and the sonic hedgehog signaling pathway effector GLI2 are concomitantly increased in papillary thyroid cancer (PTC) samples [65]. FOXE1 is a transcriptional target of GLI2 [122], and accordingly, depletion of GLI2 in PTC cell lines decreased FOXE1 levels and the expression of WNT5A. Re-expression of FOXE1 in this context 
restored WNT5 levels, suggesting that GLI2 controls WNT5A via FOXE1 in PTC [65]. Conversely, increased WNT5A expression has been observed in intestinal mesenchymal cells of FOXF2-deficient as well as FOXF1/ 2 compound heterozygous mice [79]. Ormestad et al. observed that FOXF1/2, which are also controlled by sonic hedgehog signaling, negatively regulate the expression of WNT5A via induction of Bone morphogenetic protein 4 (BMP4). Accordingly, loss of FOXF expression in embryonic mice resulted in epithelial overgrowth in the small intestine, presumably due to WNT5A-dependent $\beta$-catenin signaling activation. Furthermore, FOXG1 represses WNT8B expression and Wnt/ $\beta$-catenin signaling in Xenopus embryogenesis, again working as a downstream effector in the sonic hedgehog signaling pathway [66]. It should be noted that FOXG1-deficient mice exhibit severe developmental defects, but no changes in WNT8B expression [123], possibly indicating mammalian-specific functions of FOXG1. Collectively, these studies suggest that FOX transcription factors act as Wnt ligand regulators during tissue patterning and organogenesis, and that the aberrant reactivation of these developmental programs may contribute to cancer development and progression.

\subsubsection{Other Mechanisms of Wnt Pathway Regulation}

Besides Wnt ligands, $\beta$-catenin itself may be a transcriptional target of some FOX proteins. FOXS1 overexpression decreased the transcription of $\beta$-catenin (encoded by the CTNNB1 gene) and two Wnt target genes in gastric cancer cell lines, which was associated with decreased tumor cell proliferation in mice [87]. These findings are consistent with the observation that high expression of FOXS1 is linked to improved relapse-free survival in breast cancer patients, and that FOXS1 is highly expressed in the hedgehog but not Wnt subtype of medulloblastomas [124]. In contrast, FOXH1 increased the mRNA levels of CTNNB1 and Wnt target genes in breast cancer cell lines, and depletion of $\beta$ catenin reversed the positive effects of FOXH1 on tumor cell proliferation and invasion [69]. Cao et al. observed that FOXC1 also increases CTNNB1 expression in lung cancer cell lines, and identified a forkhead box binding site in the CTNNB1 promoter that was required for the efficient activation of $\beta$-catenin transcription [61]. Additionally, FOXC1 decreases the levels of Wnt inhibitor DKK1 in gastric cancer cell lines by direct transcriptional repression [63]. DKK1 attenuates Wnt signaling by competitive binding to LRP5/6, which blocks pathway activation and thereby reduces $\beta$-catenin protein levels [125]. Consistently, decreased tumor cell proliferation caused by FOXC1 depletion was reverted by concomitant knock-down of DKK1 [63]. FOXM1 was also recently shown to induce DKK1 in pancreatic and esophageal carcinoma cells [126]. However, Kimura et al. reported that DKK1 does not regulate Wnt signaling in these cells, but rather increases FOXM1 levels in positive feedback loop. Taken together, these results suggest that FOX transcription factors control $\beta$-catenin abundance both transcriptionally and post-translationally. At least in the case of FOXC1, these modes of action appear to work in parallel with potentially additive effects.

FOXK1 and FOXK2 have a unique mode of action in the Wnt pathway. FOXK1/2 are best known as metabolic regulators, but they have also been implicated in the pathogenesis of various types of cancer [127-129]. Wang et al. reported that FOXK1/2 directly interact with the Segment polarity protein disheveled homologs (DVL) 1-3, and facilitate their nuclear translocation [71]. DVLs are scaffold proteins required for destruction complex inhibition in the Wnt pathway [130]. In addition, nuclear DVL promotes $\beta$-catenin/TCF association, and thereby increases Wnt transcriptional activity [40,131]. Consistently, Wang et al. observed that FOXK1/2 overexpression increased Wnt/ $\beta$-catenin signaling, which was blocked by DVL depletion [71]. High FOXK1/2 levels are associated with increased Wnt target gene expression in CRC patient samples, and depletion of FOXK in CRC cell lines considerably attenuated tumor growth in vivo. Conversely, overexpression of FOXK2 in mice induced epithelial hyper-proliferation and increased Wnt transcriptional activity in intestinal crypts.

Lastly, FOXL1 may regulate Wnt signaling through a distinct mechanism as well. Perreault et al. observed that epithelial cell proliferation was increased in the digestive tract 
of FOXL1-deficient mice [82]. This increase was associated with elevated nuclear $\beta$-catenin levels, which the authors attributed to the post-transcriptional de-repression of the heparan sulfate proteoglycans (HSPG) syndecan-1 and perlecan following loss of FOXL1. HSPGs are common co-receptors in cell signaling pathways, including Wnt signaling $[5,132]$, and thus FOXL1 may attenuate epithelial cell proliferation by curbing Wnt agonist sequestration by HSPGs. Consistent with this role as a putative tumor suppressor, loss of FOXL1 has been linked to tumor progression and poor prognosis in several types of cancer, including pancreatic and gastric cancer $[133,134]$.

\subsection{Reciprocal Regulation of FOX Transcription Factors by Wnt Signaling}

TCF/LEF binding sites are highly abundant in the mammalian genome. It has been shown that Wnt/ $\beta$-catenin signaling controls the expression of thousands of genes $[111,135]$, and some FOX transcription factors have been identified as bona fide Wnt targets as well. Christensen et al. reported that FOXQ1 is one of the most highly upregulated genes in CRC, and that its expression correlates with Wnt pathway activity in CRC cell lines [136] (Figure 2). The authors demonstrated that $\beta$-catenin directly engages and activates the FOXQ1 gene promoter, which was attenuated by mutation of a TCF7L2 binding site. FOXQ1 is a potent activator of Wnt/ $\beta$-catenin signaling $[60,77]$, and thus FOXQ1 induction may trigger a positive feedback loop that promotes tumor progression in some cancers, including CRC. Similarly, $\beta$-catenin controls FOXA2 expression by direct transcriptional regulation, and high FOXA2 levels were observed in endometrial hyperplasia samples with elevated Wnt activity [137]. Class A FOX proteins are pioneer transcription factors that act as essential co-factors for various other transcription regulators, such as sex hormone receptors. Accordingly, FOXA2 has been linked to the pathogenesis of prostate and liver cancer $[138,139]$, which could be explained in part by dysregulated Wnt signaling. Others have demonstrated the regulation of FOXC1/2, FOXD3, FOXJ1, and FOXN1 expression by $\beta$-catenin/TCF in different contexts [140-143], but the relevance for cancer biology is less clear in these cases.

Finally, a separate mode of reciprocal regulation has been described for FOXM1. Chen et al. identified FOXM1 as a target of Wnt/STOP signaling [72]. In Wnt-inactive cells, FOXM1 is marked for proteasomal degradation by the ubiquitin ligase F-box/WD repeatcontaining protein 7 (FBXW7) following phosphorylation by Glycogen synthase kinase-3 (GSK3) within the destruction complex. Upon Wnt pathway activation, the destruction complex is inhibited, which results in the concomitant stabilization of $\beta$-catenin and FOXM1. FBXW7 is a major tumor suppressor that is frequently mutated in cancer [144], and part of its effect can likely be attributed to the post-translational repression of FOXM1. Whether Wnt/STOP controls the stability of other FOX transcription factors is unknown, but several FOX proteins, including FOXA1/3, FOXI1, and FOXK2 contain GSK3/FBXW7 recognition motifs, and may be subject to Wnt-dependent stability regulation.

\subsection{Common Themes and Open Questions}

As discussed in the preceding chapters, there is mounting evidence that FOX transcription factors are common regulators of Wnt signaling pathways, particularly Wnt/ $\beta$-catenin signaling. Given that both $\beta$-catenin and FOX proteins can be traced back to early metazoan ancestors [145,146], it is conceivable that the reciprocal regulation of FOX and Wnt arose during the evolution of multicellular organisms, and that it is conserved throughout the animal kingdom. Support for this hypothesis comes from the observation that the functions of some FOX transcription factors in the Wnt pathway are shared between mammals and lower organisms, such as the Wnt inhibitory role of FOXO proteins in nematodes [106], or the activation of $\beta$-catenin target genes by FOXH1 in frogs $[68,69]$. These examples also illustrate that both positive and negative regulation of Wnt signaling by FOX proteins have likely appeared early in evolution. What could be the purpose of Wnt pathway regulation by FOX transcription factors? One likely possibility is that is has emerged to control the precise temporal and spatial activity of Wnt signaling throughout an organism. 
With increasing organismal complexity, ever more precisely controlled Wnt activity is required for tissue development and homeostasis. Unlike the core Wnt pathway components, which have diversified little during evolution [147], the FOX transcription factor family continues to evolve, and its members exhibit highly distinct expression patterns [48,49]. Thus, FOX proteins are ideally suited to act as rheostats of Wnt activity in specific cell types, tissues, and developmental stages. It is therefore an open challenge to determine to what extent and in which contexts FOX transcription factors contribute to the regulation of Wnt signaling.

Another unanswered question is whether findings for one FOX protein can be extrapolated to other family members. As outlined above, multiple FOX transcription factors interact with $\beta$-catenin and thereby regulate its stability, activity, and subcellular localization (Figure 4). It is not clear if this is a conserved feature in the FOX family, or whether it arose independently in different family members through convergent evolution. Zhang et al. mapped the minimal $\beta$-catenin-binding sequence of FOXM1 to its highly conserved forkhead box [73], which suggests that the DNA-binding domain of FOX transcription factors may be a shared $\beta$-catenin interaction surface. However, it has been shown that the forkhead box of FOXO1 is dispensable for $\beta$-catenin binding [106]. Moreover, in work from our group, we did not observe interaction of full-length FOXB2 with $\beta$-catenin [60]. Conversely, $\beta$-catenin engages the structurally unrelated FOXG1 and FOXO1 via its $\mathrm{N}$-terminal, and FOXM1 through its C-terminal Armadillo repeats $[67,73,106]$, again arguing against a conserved mode of action.

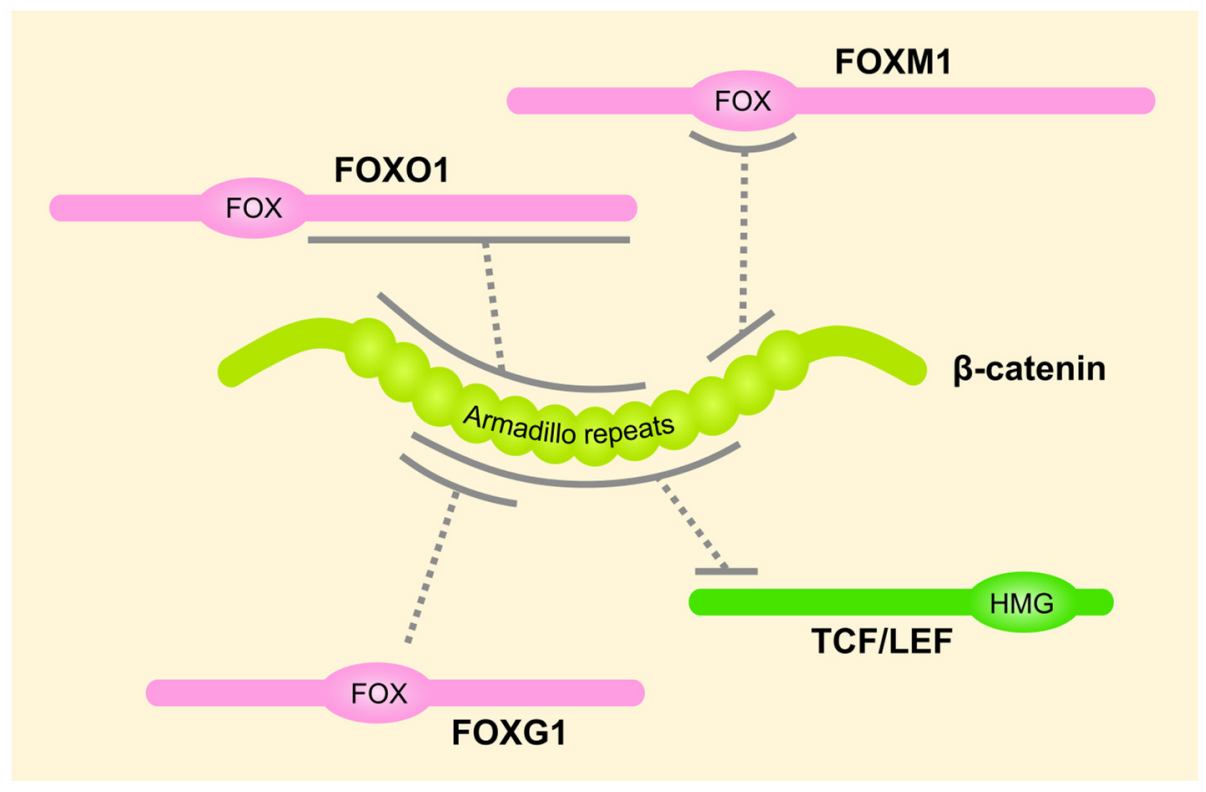

Figure 4. Schematic representation of known FOX protein/ $\beta$-catenin interactions. Solid grey lines indicate experimentally mapped binding domains. All proteins are shown in N-to-C-terminal orientation. FOX, (DNA-binding) forkhead box; HMG, (DNA-binding) high mobility group box.

On the other hand, the role of FOX proteins in the transcriptional regulation of Wnt pathway components may be underappreciated. Our observation that FOXB2 regulates the expression of most Wnt molecules raises the possibility that the majority of Wnt ligands are under transcriptional control by FOX proteins [60]. Many FOX transcription factors have overlapping DNA recognition motifs, and therefore act partly redundantly in target gene expression $[53,54]$. Consistently, FOXQ1 was shown to regulate some of the same Wnt ligands as FOXB2 [77], and WNT5A transcription is regulated by FOXC1, FOXE1, and FOXF1/2 in different contexts [62,65,79]. Additionally, motif analysis of the FOXC1 binding site that Cao et al. identified in the CTNNB1 promoter suggests that various other FOX proteins may engage this site with similar affinity, and thereby control Wnt/ $\beta$-catenin 
signaling transcriptionally [61]. Thus, it is of considerable interest to further investigate the regulation of Wnt pathway genes by FOX transcription factors.

It should be noted that many of the studies referenced here have limitations that need to be considered when interpreting the results. Firstly, FOX proteins are often studied by ectopic overexpression, which may cause them to work in ways that are not physiologically relevant. Secondly, in most cancers, multiple FOX family members are dysregulated at the same time (see Figure 2), which may have combinatorial effects on the Wnt pathway. Lastly, regulation of Wnt signaling is just one the many functions of FOX transcription factors. Thus, whether an observation such as tumor growth following FOX induction can actually be attributed to Wnt pathway activation is usually hard to distinguish from alternative explanations. Clearly, a lot of work still lies ahead in determining how the regulation of Wnt signaling by FOX proteins contributes to cancer biology. However, the effort seems to be well worth it considering the exciting discoveries that have been made so far.

\subsection{Therapeutic Targeting of FOX-dependent Wnt Signaling}

Could the FOX-dependent regulation of Wnt signaling be targeted for cancer therapy? While it is too early to answer this question with confidence, there are some promising results from preclinical studies that give reason to be optimistic. As discussed earlier, high nuclear $\beta$-catenin levels confer apoptosis resistance to colorectal cancer cells treated with PI3K/PKB inhibitors [110]. Simultaneous inhibition of PKB and Wnt signaling reverts this effect, and suppresses tumor growth in patient-derived cancer cells $[110,148]$. Moreover, a recently developed FOXM1 inhibitor reduces $\beta$-catenin abundance and activity in different cancer cell lines, and attenuates tumor growth in mouse xenograft models [149]. In the context of Wnt signaling, there are drugs that block the interaction between TCF and $\beta$-catenin or CBP, of which some have already entered clinical trials [22]. It is conceivable that similar compounds could target the interaction of FOX proteins with Wnt pathway components, which may aid in the safe and precise treatment of Wnt-dependent cancers.

\section{Conclusions}

The Wnt pathway and FOX transcription factors are ancient regulators of metazoan cell signaling, and their interaction is intimately linked not only to normal development and tissue homeostasis, but also to cancer initiation and progression. Considering the sheer number of FOX family members, and the fact that many of them have not been studied in great detail, it is highly likely that many important connections in FOX-dependent Wnt signaling still await discovery, and that these findings will further refine our understanding of cell signaling in health and disease.

Funding: Research in the Koch laboratory is funded by grants from the Knut and Alice Wallenberg Foundation (KAW), the Swedish Research Council (VR), and the Swedish Cancer Society (Cancerfonden).

Institutional Review Board Statement: Not applicable.

Informed Consent Statement: Not applicable.

Data Availability Statement: Figure 2 was generated using public gene expression data from The Cancer Genome Atlas (TCGA Research Network). Cancer and matched normal data were accessed and analyzed in GEPIA 2 (http:/ / gepia2.cancer-pku.cn/\#index, accessed on 10 June 2021) [150], using the ANOVA differential expression option. The following TCGA datasets were used: GBM (Brain), BRCA (Breast), COAD (Colon), LUAD (Lung), and PRAD (Prostate). Results were visualized using R 4.1.0 [151].

Conflicts of Interest: The author declares no conflict of interest. The funders had no role in the analysis of data, in the writing of the manuscript, or in the decision to publish the results.

\section{References}

1. Nusse, R.; Clevers, H. Wnt/ $\beta$-Catenin Signaling, Disease, and Emerging Therapeutic Modalities. Cell 2017, 169, 985-999. [CrossRef] 
2. Steinhart, Z.; Angers, S. Wnt Signaling in Development and Tissue Homeostasis. Development 2018, 145, dev146589. [CrossRef]

3. Boonekamp, K.E.; Heo, I.; Artegiani, B.; Asra, P.; van Son, G.; de Ligt, J.; Clevers, H. Identification of Novel Human Wnt Target Genes Using Adult Endodermal Tissue-Derived Organoids. Dev. Biol. 2021, 474, 37-47. [CrossRef] [PubMed]

4. Acebron, S.P.; Niehrs, C. $\beta$-Catenin-Independent Roles of Wnt/LRP6 Signaling. Trends Cell Biol. 2016, 26, 956-967. [CrossRef] [PubMed]

5. Niehrs, C. The Complex World of WNT Receptor Signalling. Nat. Rev. Mol. Cell Biol. 2012, 13, 767-779. [CrossRef]

6. Jackstadt, R.; Hodder, M.C.; Sansom, O.J. WNT and $\beta$-Catenin in Cancer: Genes and Therapy. Annu. Rev. Cancer Biol. 2020, 4, 177-196. [CrossRef]

7. Zhan, T.; Rindtorff, N.; Boutros, M. Wnt Signaling in Cancer. Oncogene 2017, 36, 1461-1473. [CrossRef]

8. Rijsewijk, F.; Schuermann, M.; Wagenaar, E.; Parren, P.; Weigel, D.; Nusse, R. The Drosophila Homology of the Mouse Mammary Oncogene Int-1 Is Identical to the Segment Polarity Gene Wingless. Cell 1987, 50, 649-657. [CrossRef]

9. Cancer Genome Atlas Network. Comprehensive Molecular Characterization of Human Colon and Rectal Cancer. Nature 2012, 487, 330-337. [CrossRef]

10. Voloshanenko, O.; Erdmann, G.; Dubash, T.D.; Augustin, I.; Metzig, M.; Moffa, G.; Hundsrucker, C.; Kerr, G.; Sandmann, T.; Anchang, B.; et al. Wnt Secretion Is Required to Maintain High Levels of Wnt Activity in Colon Cancer Cells. Nat. Commun. 2013, 4, 2610. [CrossRef] [PubMed]

11. Dow, L.E.; O’Rourke, K.P.; Simon, J.; Tschaharganeh, D.F.; van Es, J.H.; Clevers, H.; Lowe, S.W. Apc Restoration Promotes Cellular Differentiation and Reestablishes Crypt Homeostasis in Colorectal Cancer. Cell 2015, 161, 1539-1552. [CrossRef]

12. Murillo-Garzón, V.; Kypta, R. WNT Signalling in Prostate Cancer. Nat. Rev. Urol. 2017, 14, 683-696. [CrossRef]

13. Zeng, G.; Germinaro, M.; Micsenyi, A.; Monga, N.K.; Bell, A.; Sood, A.; Malhotra, V.; Sood, N.; Midda, V.; Monga, D.K.; et al. Aberrant Wnt/Beta-Catenin Signaling in Pancreatic Adenocarcinoma. Neoplasia 2006, 8, 279-289. [CrossRef] [PubMed]

14. Vincan, E.; Barker, N. The Upstream Components of the Wnt Signalling Pathway in the Dynamic EMT and MET Associated with Colorectal Cancer Progression. Clin. Exp. Metastasis 2008, 25, 657-663. [CrossRef] [PubMed]

15. Heuberger, J.; Birchmeier, W. Interplay of Cadherin-Mediated Cell Adhesion and Canonical Wnt Signaling. Cold Spring Harb. Perspect. Biol. 2010, 2, a002915. [CrossRef] [PubMed]

16. Qi, J.; Yu, Y.; Akilli Öztürk, Ö.; Holland, J.D.; Besser, D.; Fritzmann, J.; Wulf-Goldenberg, A.; Eckert, K.; Fichtner, I.; Birchmeier, W. New Wnt/ $\beta$-Catenin Target Genes Promote Experimental Metastasis and Migration of Colorectal Cancer Cells through Different Signals. Gut 2016, 65, 1690-1701. [CrossRef]

17. Wu, Z.-Q.; Li, X.-Y.; Hu, C.Y.; Ford, M.; Kleer, C.G.; Weiss, S.J. Canonical Wnt Signaling Regulates Slug Activity and Links Epithelial-Mesenchymal Transition with Epigenetic Breast Cancer 1, Early Onset (BRCA1) Repression. Proc. Natl. Acad. Sci. USA 2012, 109, 16654-16659. [CrossRef] [PubMed]

18. Yook, J.I.; Li, X.-Y.; Ota, I.; Fearon, E.R.; Weiss, S.J. Wnt-Dependent Regulation of the E-cadherin Repressor Snail. J. Biol. Chem. 2005, 280, 11740-11748. [CrossRef]

19. Kohn, A.D.; Moon, R.T. Wnt and Calcium Signaling: $\beta$-Catenin-Independent Pathways. Cell Calcium 2005, 38, 439-446. [CrossRef]

20. Wang, Y. Wnt/Planar Cell Polarity Signaling: A New Paradigm for Cancer Therapy. Mol. Cancer Ther. 2009, 8, 2103-2109. [CrossRef]

21. Jung, Y.-S.; Park, J.-I. Wnt Signaling in Cancer: Therapeutic Targeting of Wnt Signaling beyond B-Catenin and the Destruction Complex. Exp. Mol. Med. 2020, 52, 183-191. [CrossRef]

22. Krishnamurthy, N.; Kurzrock, R. Targeting the Wnt/Beta-Catenin Pathway in Cancer: Update on Effectors and Inhibitors. Cancer Treat. Rev. 2018, 62, 50-60. [CrossRef] [PubMed]

23. Kahn, M. Can We Safely Target the WNT Pathway? Nat. Rev. Drug Discov. 2014, 13, 513-532. [CrossRef]

24. Alok, A.; Lei, Z.; Jagannathan, N.S.; Kaur, S.; Harmston, N.; Rozen, S.G.; Tucker-Kellogg, L.; Virshup, D.M. Wnt Proteins Synergize to Activate $\beta$-Catenin Signaling. J. Cell Sci. 2017, 130, 1532-1544. [PubMed]

25. Dijksterhuis, J.P.; Baljinnyam, B.; Stanger, K.; Sercan, H.O.; Ji, Y.; Andres, O.; Rubin, J.S.; Hannoush, R.N.; Schulte, G. Systematic Mapping of WNT-FZD Protein Interactions Reveals Functional Selectivity by Distinct WNT-FZD Pairs. J. Biol. Chem. 2015, 290, 6789-6798. [CrossRef]

26. Eubelen, M.; Bostaille, N.; Cabochette, P.; Gauquier, A.; Tebabi, P.; Dumitru, A.C.; Koehler, M.; Gut, P.; Alsteens, D.; Stainier, D.Y. A Molecular Mechanism for Wnt Ligand-Specific Signaling. Science 2018, 361, eaat1178. [CrossRef] [PubMed]

27. Voloshanenko, O.; Gmach, P.; Winter, J.; Kranz, D.; Boutros, M. Mapping of Wnt-Frizzled Interactions by Multiplex CRISPR Targeting of Receptor Gene Families. FASEB J. 2017, 31, 4832-4844. [CrossRef]

28. Le, N.H.; Franken, P.; Fodde, R. Tumour-Stroma Interactions in Colorectal Cancer: Converging on Beta-Catenin Activation and Cancer Stemness. Br. J. Cancer 2008, 98, 1886-1893. [CrossRef]

29. Mosimann, C.; Hausmann, G.; Basler, K. $\beta$-Catenin Hits Chromatin: Regulation of Wnt Target Gene Activation. Nat. Rev. Mol. Cell Biol. 2009, 10, 276-286. [CrossRef]

30. Nakamura, Y.; de Paiva Alves, E.; Veenstra, G.J.C.; Hoppler, S. Tissue-and Stage-Specific Wnt Target Gene Expression Is Controlled Subsequent to $\beta$-Catenin Recruitment to Cis-Regulatory Modules. Development 2016, 143, 1914-1925. [CrossRef]

31. Söderholm, S.; Cantù, C. The WNT/ $\beta$-Catenin Dependent Transcription: A Tissue-Specific Business. Wiley Interdiscip. Rev. Syst. Biol. Med. 2020, 13, e1511. 
32. Ramakrishnan, A.-B.; Sinha, A.; Fan, V.B.; Cadigan, K.M. The Wnt Transcriptional Switch: TLE Removal or Inactivation? Bioessays 2018, 40, 1700162. [CrossRef]

33. Cadigan, K.M.; Waterman, M.L. TCF/LEFs and Wnt Signaling in the Nucleus. Cold Spring Harb. Perspect. Biol. 2012, 4, a007906. [CrossRef]

34. Mayer, C.-D.; Magon de La Giclais, S.; Alsehly, F.; Hoppler, S. Diverse LEF/TCF Expression in Human Colorectal Cancer Correlates with Altered Wnt-Regulated Transcriptome in a Meta-Analysis of Patient Biopsies. Genes 2020, 11, 538. [CrossRef]

35. Moreira, S.; Polena, E.; Gordon, V.; Abdulla, S.; Mahendram, S.; Cao, J.; Blais, A.; Wood, G.A.; Dvorkin-Gheva, A.; Doble, B.W. A Single TCF Transcription Factor, Regardless of Its Activation Capacity, Is Sufficient for Effective Trilineage Differentiation of ESCs. Cell Rep. 2017, 20, 2424-2438. [CrossRef]

36. Chesire, D.R.; Isaacs, W.B. Ligand-Dependent Inhibition of B-Catenin/TCF Signaling by Androgen Receptor. Oncogene 2002, 21, 8453-8469. [CrossRef]

37. Truica, C.I.; Byers, S.; Gelmann, E.P. $\beta$-Catenin Affects Androgen Receptor Transcriptional Activity and Ligand Specificity. Cancer Res. 2000, 60, 4709-4713. [PubMed]

38. Davidson, K.C.; Adams, A.M.; Goodson, J.M.; McDonald, C.E.; Potter, J.C.; Berndt, J.D.; Biechele, T.L.; Taylor, R.J.; Moon, R.T. Wnt/ $\beta$-Catenin Signaling Promotes Differentiation, Not Self-Renewal, of Human Embryonic Stem Cells and Is Repressed by Oct4. Proc. Natl. Acad. Sci. USA 2012, 109, 4485-4490. [CrossRef] [PubMed]

39. Kelly, K.F.; Ng, D.Y.; Jayakumaran, G.; Wood, G.A.; Koide, H.; Doble, B.W. $\beta$-Catenin Enhances Oct-4 Activity and Reinforces Pluripotency through a TCF-Independent Mechanism. Cell Stem Cell 2011, 8, 214-227. [CrossRef] [PubMed]

40. Gan, X.-Q.; Wang, J.-Y.; Xi, Y.; Wu, Z.-L.; Li, Y.-P.; Li, L. Nuclear Dvl, c-Jun, Beta-Catenin, and TCF Form a Complex Leading to Stabilization of Beta-Catenin-TCF Interaction. J. Cell Biol. 2008, 180, 1087-1100. [CrossRef]

41. Nateri, A.S.; Spencer-Dene, B.; Behrens, A. Interaction of Phosphorylated C-Jun with TCF4 Regulates Intestinal Cancer Development. Nature 2005, 437, 281-285. [CrossRef] [PubMed]

42. Sancho, R.; Nateri, A.S.; De Vinuesa, A.G.; Aguilera, C.; Nye, E.; Spencer-Dene, B.; Behrens, A. JNK Signalling Modulates Intestinal Homeostasis and Tumourigenesis in Mice. EMBO J. 2009, 28, 1843-1854. [CrossRef]

43. Zimmerli, D.; Borrelli, C.; Jauregi-Miguel, A.; Söderholm, S.; Brütsch, S.; Doumpas, N.; Reichmuth, J.; Murphy-Seiler, F.; Aguet, M.; Basler, K.; et al. TBX3 Acts as Tissue-Specific Component of the Wnt/ $\beta$-Catenin Transcriptional Complex. eLife 2020, 9, e58123. [CrossRef] [PubMed]

44. Sellak, H.; Wu, S.; Lincoln, T.M. KLF4 and SOX9 Transcription Factors Antagonize B-Catenin and Inhibit TCF-Activity in Cancer Cells. Biochim. Biophys. Acta Mol. Cell Res. 2012, 1823, 1666-1675. [CrossRef] [PubMed]

45. Sinha, A.; Fan, V.B.; Ramakrishnan, A.-B.; Engelhardt, N.; Kennell, J.; Cadigan, K.M. Repression of Wnt/ $\beta$-Catenin Signaling by SOX9 and Mastermind-Like Transcriptional Coactivator 2. Sci Adv. 2021, 7, eabe0849. [CrossRef]

46. Topol, L.; Chen, W.; Song, H.; Day, T.F.; Yang, Y. Sox9 Inhibits Wnt Signaling by Promoting $\beta$-Catenin Phosphorylation in the Nucleus. J. Biol. Chem. 2009, 284, 3323-3333. [CrossRef]

47. Bastide, P.; Darido, C.; Pannequin, J.; Kist, R.; Robine, S.; Marty-Double, C.; Bibeau, F.; Scherer, G.; Joubert, D.; Hollande, F. Sox9 Regulates Cell Proliferation and Is Required for Paneth Cell Differentiation in the Intestinal Epithelium. J. Cell Biol. 2007, 178, 635-648. [CrossRef]

48. Hannenhalli, S.; Kaestner, K.H. The Evolution of Fox Genes and Their Role in Development and Disease. Nat. Rev. Genet. 2009, 10, 233-240. [CrossRef]

49. Herman, L.; Todeschini, A.-L.; Veitia, R.A. Forkhead Transcription Factors in Health and Disease. Trends Genet. 2021, 37, 460-475. [CrossRef]

50. Golson, M.L.; Kaestner, K.H. Fox Transcription Factors: From Development to Disease. Development 2016, 143, 4558-4570. [CrossRef]

51. Lam, E.W.F.; Brosens, J.J.; Gomes, A.R.; Koo, C.-Y. Forkhead Box Proteins: Tuning Forks for Transcriptional Harmony. Nat. Rev. Cancer 2013, 13, 482-495. [CrossRef]

52. Myatt, S.S.; Lam, E.W.-F. The Emerging Roles of Forkhead Box (Fox) Proteins in Cancer. Nat. Rev. Cancer 2007, 7, 847-859. [CrossRef]

53. Chen, X.; Ji, Z.; Webber, A.; Sharrocks, A.D. Genome-Wide Binding Studies Reveal DNA Binding Specificity Mechanisms and Functional Interplay amongst Forkhead Transcription Factors. Nucleic Acids Res. 2016, 44, 1566-1578. [CrossRef]

54. Jolma, A.; Yan, J.; Whitington, T.; Toivonen, J.; Nitta, K.R.; Rastas, P.; Morgunova, E.; Enge, M.; Taipale, M.; Wei, G.; et al. DNA-Binding Specificities of Human Transcription Factors. Cell 2013, 152, 327-339. [CrossRef]

55. Nakagawa, S.; Gisselbrecht, S.S.; Rogers, J.M.; Hartl, D.L.; Bulyk, M.L. DNA-Binding Specificity Changes in the Evolution of Forkhead Transcription Factors. Proc. Natl. Acad. Sci. USA 2013, 110, 12349-12354. [CrossRef] [PubMed]

56. Li, X.; Wang, W.; Wang, J.; Malovannaya, A.; Xi, Y.; Li, W.; Guerra, R.; Hawke, D.H.; Qin, J.; Chen, J. Proteomic Analyses Reveal Distinct Chromatin-Associated and Soluble Transcription Factor Complexes. Mol. Syst. Biol. 2015, 11, 775. [CrossRef] [PubMed]

57. Moparthi, L.; Koch, S. A Uniform Expression Library for the Exploration of FOX Transcription Factor Biology. Differentiation 2020, 115, 30-36. [CrossRef] [PubMed]

58. Penna-Martinez, M.; Epp, F.; Kahles, H.; Ramos-Lopez, E.; Hinsch, N.; Hansmann, M.-L.; Selkinski, I.; Grünwald, F.; Holzer, K.; Bechstein, W.O. FOXE1 Association with Differentiated Thyroid Cancer and Its Progression. Thyroid 2014, 24, 845-851. [CrossRef] [PubMed] 
59. Trueba, S.S.; Augé, J.1.; Mattei, G.r.; Etchevers, H.; Martinovic, J.; Czernichow, P.; Vekemans, M.; Polak, M.; Attié-Bitach, T. PAX8, TITF1, and FOXE1 Gene Expression Patterns during Human Development: New Insights into Human Thyroid Development and Thyroid Dysgenesis-Associated Malformations. J. Clin. Endocrinol. Metab. 2005, 90, 455-462. [CrossRef]

60. Moparthi, L.; Pizzolato, G.; Koch, S. Wnt Activator FOXB2 Drives the Neuroendocrine Differentiation of Prostate Cancer. Proc. Natl. Acad. Sci. USA 2019, 116, 22189-22195. [CrossRef]

61. Cao, S.; Wang, Z.; Gao, X.; He, W.; Cai, Y.; Chen, H.; Xu, R. FOXC1 Induces Cancer Stem Cell-Like Properties through Upregulation of Beta-Catenin in NSCLC. J. Exp. Clin. Cancer Res. 2018, 37, 220. [CrossRef] [PubMed]

62. Han, B.; Zhou, B.; Qu, Y.; Gao, B.; Xu, Y.; Chung, S.; Tanaka, H.; Yang, W.; Giuliano, A.E.; Cui, X. FOXC1-Induced Non-Canonical WNT5A-MMP7 Signaling Regulates Invasiveness in Triple-Negative Breast Cancer. Oncogene 2018, 37, 1399-1408. [CrossRef]

63. Jiang, J.; Li, J.; Yao, W.; Wang, W.; Shi, B.; Yuan, F.; Dong, J.; Zhang, H. FOXC1 Negatively Regulates DKK1 Expression to Promote Gastric Cancer Cell Proliferation through Activation of Wnt Signaling Pathway. Front. Cell Dev. Biol. 2021, 9, 943. [CrossRef] [PubMed]

64. Gozo, M.C.; Aspuria, P.J.; Cheon, D.J.; Walts, A.E.; Berel, D.; Miura, N.; Karlan, B.Y.; Orsulic, S. Foxc2 Induces Wnt4 and Bmp4 Expression during Muscle Regeneration and Osteogenesis. Cell Death Differ. 2013, 20, 1031-1042. [CrossRef]

65. Ma, J.; Huang, X.; Li, Z.; Shen, Y.; Lai, J.; Su, Q.; Zhao, J.; Xu, J. FOXE1 Supports the Tumor Promotion of Gli2 on Papillary Thyroid Carcinoma by the Wnt/ $\beta$-Catenin Pathway. J. Cell. Physiol. 2019, 234, 17739-17748. [CrossRef]

66. Danesin, C.; Peres, J.N.; Johansson, M.; Snowden, V.; Cording, A.; Papalopulu, N.; Houart, C. Integration of Telencephalic Wnt and Hedgehog Signaling Center Activities by Foxg1. Dev. Cell 2009, 16, 576-587. [CrossRef]

67. Zheng, X.; Lin, J.; Wu, H.; Mo, Z.; Lian, Y.; Wang, P.; Hu, Z.; Gao, Z.; Peng, L.; Xie, C. Forkhead Box (FOX) G1 Promotes Hepatocellular Carcinoma Epithelial-Mesenchymal Transition by Activating Wnt Signal through Forming T-Cell Factor-4/BetaCatenin/FOXG1 Complex. J. Exp. Clin. Cancer Res. 2019, 38, 475. [CrossRef]

68. Afouda, B.A.; Nakamura, Y.; Shaw, S.; Charney, R.M.; Paraiso, K.D.; Blitz, I.L.; Cho, K.W.Y.; Hoppler, S. Foxh1/Nodal Defines Context-Specific Direct Maternal Wnt/ $\beta$-Catenin Target Gene Regulation in Early Development. iScience 2020, $23,101314$. [CrossRef] [PubMed]

69. Liu, Y.; Zhang, L.; Meng, Y.; Huang, L. Benzyl Isothiocyanate Inhibits Breast Cancer Cell Tumorigenesis via Repression of the FoxH1-Mediated Wnt/ $\beta$-Catenin Pathway. Int. J. Clin. Exp. Med. 2015, 8, 17601-17611.

70. Liu, K.; Fan, J.; Wu, J. Forkhead box protein J1 (FOXJ1) Is Overexpressed in Colorectal Cancer and Promotes Nuclear Translocation of $\beta$-Catenin in SW620 Cells. Med. Sci. Monit. Int. Med. J. Exp. Clin. Res. 2017, 23, 856. [CrossRef]

71. Wang, W.; Li, X.; Lee, M.; Jun, S.; Aziz, K.E.; Feng, L.; Tran, M.K.; Li, N.; McCrea, P.D.; Park, J.-I.; et al. FOXKs Promote Wnt/ $\beta$-Catenin Signaling by Translocating DVL into the Nucleus. Dev. Cell 2015, 32, 707-718. [CrossRef]

72. Chen, Y.; Li, Y.; Xue, J.; Gong, A.; Yu, G.; Zhou, A.; Lin, K.; Zhang, S.; Zhang, N.; Gottardi, C.J. Wnt-Induced Deubiquitination Foxm1 Ensures Nucleus $\beta$-Catenin Transactivation. EMBO J. 2016, 35, 668-684. [CrossRef] [PubMed]

73. Zhang, N.; Wei, P.; Gong, A.; Chiu, W.-T.; Lee, H.-T.; Colman, H.; Huang, H.; Xue, J.; Liu, M.; Wang, Y.; et al. FoxM1 Promotes $\beta$ Catenin Nuclear Localization and Controls Wnt Target-Gene Expression and Glioma Tumorigenesis. Cancer Cell 2011, 20, 427-442. [CrossRef]

74. Walker, M.P.; Stopford, C.M.; Cederlund, M.; Fang, F.; Jahn, C.; Rabinowitz, A.D.; Goldfarb, D.; Graham, D.M.; Yan, F.; Deal, A.M.; et al. FOXP1 Potentiates Wnt/ $\beta$-Catenin Signaling in Diffuse Large B Cell Lymphoma. Sci. Signal. 2015, 8, ra12 [CrossRef] [PubMed]

75. Yang, S.; Liu, Y.; Li, M.-Y.; Ng, C.S.H.; Yang, S.-L.; Wang, S.; Zou, C.; Dong, Y.; Du, J.; Long, X.; et al. FOXP3 Promotes Tumor Growth and Metastasis by Activating Wnt/ $\beta$-Catenin Signaling Pathway and EMT in Non-Small Cell Lung Cancer. Mol. Cancer 2017, 16, 124. [CrossRef] [PubMed]

76. Bagati, A.; Bianchi-Smiraglia, A.; Moparthy, S.; Kolesnikova, K.; Fink, E.E.; Lipchick, B.C.; Kolesnikova, M.; Jowdy, P.; Polechetti, A.; Mahpour, A.; et al. Melanoma Suppressor Functions of the Carcinoma Oncogene FOXQ1. Cell Rep. 2017, 20, 2820-2832. [CrossRef] [PubMed]

77. Xiang, L.; Zheng, J.; Zhang, M.; Ai, T.; Cai, B. FOXQ1 Promotes the Osteogenic Differentiation of Bone Mesenchymal Stem Cells Via Wnt/ $\beta$-Catenin Signaling by Binding with ANXA2. Stem Cell Res. Ther. 2020, 11, 403. [CrossRef]

78. Wang, X.-H.; Cui, Y.-X.; Wang, Z.-M.; Liu, J. Down-Regulation of FOXR2 Inhibits Non-Small Cell Lung Cancer Cell Proliferation and Invasion through the Wnt/ $\beta$-Catenin Signaling Pathway. Biochem. Biophys. Res. Commun. 2018, 500, 229-235. [CrossRef]

79. Ormestad, M.; Astorga, J.; Landgren, H.; Wang, T.; Johansson, B.R.; Miura, N.; Carlsson, P. Foxf1 and Foxf2 Control Murine Gut Development by Limiting Mesenchymal Wnt Signaling and Promoting Extracellular Matrix Production. Development 2006, 133, 833-843. [CrossRef]

80. Higashimori, A.; Dong, Y.; Zhang, Y.; Kang, W.; Nakatsu, G.; Ng, S.S.M.; Arakawa, T.; Sung, J.J.Y.; Chan, F.K.L.; Yu, J. Forkhead Box F2 Suppresses Gastric Cancer through a Novel FOXF2-IRF2BPL- $\beta$-Catenin Signaling Axis. Cancer Res. 2018, 78, $1643-1656$. [CrossRef]

81. Nik, A.M.; Reyahi, A.; Pontén, F.; Carlsson, P. Foxf2 in Intestinal Fibroblasts Reduces Numbers of Lgr5+ Stem Cells and Adenoma Formation by Inhibiting Wnt Signaling. Gastroenterology 2013, 144, 1001-1011. [CrossRef] [PubMed]

82. Perreault, N.; Katz, J.P.; Sackett, S.D.; Kaestner, K.H. Foxl1 Controls the Wnt/ $\beta$-Catenin Pathway by Modulating the Expression of Proteoglycans in the Gut. J. Biol. Chem. 2001, 276, 43328-43333. [CrossRef] [PubMed] 
83. Dai, Y.; Wang, M.; Wu, H.; Xiao, M.; Liu, H.; Zhang, D. Loss of FOXN3 in Colon Cancer Activates Beta-Catenin/TCF Signaling and Promotes the Growth and Migration of Cancer Cells. Oncotarget 2017, 8, 9783-9793. [CrossRef]

84. Ling, J.; Wang, F.; Liu, C.; Dong, X.; Xue, Y.; Jia, X.; Song, W.; Li, Q. FOXO1-Regulated lncRNA LINC01197 Inhibits Pancreatic Adenocarcinoma Cell Proliferation by Restraining Wnt/ $\beta$-Catenin Signaling. J. Exp. Clin. Cancer Res. 2019, 38, 179. [CrossRef]

85. Hoogeboom, D.; Essers, M.A.; Polderman, P.E.; Voets, E.; Smits, L.M.; Boudewijn, M.T. Interaction of FOXO with $\beta$-Catenin Inhibits $\beta$-Catenin/T Cell Factor Activity. J. Biol. Chem. 2008, 283, 9224-9230. [CrossRef]

86. Liu, H.; Yin, J.; Wang, H.; Jiang, G.; Deng, M.; Zhang, G.; Bu, X.; Cai, S.; Du, J.; He, Z. FOXO3a Modulates WNT/ $\beta-C a t e n i n$ Signaling and Suppresses Epithelial-to-Mesenchymal Transition in Prostate Cancer Cells. Cell. Signal. 2015, 27, 510-518. [CrossRef]

87. Lu, Q.; Ma, X.; Li, Y.; Song, W.; Zhang, L.; Shu, Y.; Wan, B. Overexpression of FOXS1 in Gastric Cancer Cell Lines Inhibits Proliferation, Metastasis, and Epithelial-Mesenchymal Transition of Tumor Through Downregulating Wnt/ $\beta$-Catenin Pathway. J. Cell. Biochem. 2019, 120, 2897-2907. [CrossRef]

88. Gong, A.; Huang, S. FoxM1 and Wnt/ $\beta$-Catenin Signaling in Glioma Stem Cells. Cancer Res. 2012, 72, 5658-5662. [CrossRef]

89. Halasi, M.; Gartel, A.L. FOX (M1) News-It Is Cancer. Mol. Cancer Ther. 2013, 12, 245-254. [CrossRef]

90. Raychaudhuri, P.; Park, H.J. FoxM1: A Master Regulator of Tumor Metastasis. Cancer Res. 2011, 71, 4329-4333. [CrossRef] [PubMed]

91. Gartel, A.L. FOXM1 in Cancer: Interactions and Vulnerabilities. Cancer Res. 2017, 77, 3135-3139. [CrossRef] [PubMed]

92. Quan, M.; Cui, J.; Xia, T.; Jia, Z.; Xie, D.; Wei, D.; Huang, S.; Huang, Q.; Zheng, S.; Xie, K. Merlin/NF2 Suppresses Pancreatic Tumor Growth and Metastasis by Attenuating the FOXM1-Mediated Wnt/ $\beta$-Catenin Signaling. Cancer Res. 2015, 75, 4778-4789. [CrossRef]

93. Vasudevan, H.N.; Braunstein, S.E.; Phillips, J.J.; Pekmezci, M.; Tomlin, B.A.; Wu, A.; Reis, G.F.; Magill, S.T.; Zhang, J.; Feng, F.Y. Comprehensive Molecular Profiling Identifies FOXM1 as a Key Transcription Factor for Meningioma Proliferation. Cell Rep. 2018, 22, 3672-3683. [CrossRef] [PubMed]

94. Chen, J.; Wu, X.; Xing, Z.; Ma, C.; Xiong, W.; Zhu, X.; He, X. FOXG1 Expression Is Elevated in Glioma and Inhibits Glioma Cell Apoptosis. J. Cancer 2018, 9, 778-783. [CrossRef] [PubMed]

95. Verginelli, F.; Perin, A.; Dali, R.; Fung, K.H.; Lo, R.; Longatti, P.; Guiot, M.-C.; Del Maestro, R.F.; Rossi, S.; Di Porzio, U. Transcription Factors FOXG1 and Groucho/TLE Promote Glioblastoma Growth. Nat. Commun. 2013, 4, 1-16. [CrossRef] [PubMed]

96. Abedalthagafi, M.S.; Wu, M.P.; Merrill, P.H.; Du, Z.; Woo, T.; Sheu, S.H.; Hurwitz, S.; Ligon, K.L.; Santagata, S. Decreased FOXJ1 Expression and Its Ciliogenesis Programme in Aggressive Ependymoma and Choroid Plexus Tumours. J. Pathol. 2016, 238, 584-597. [CrossRef]

97. Chen, H.W.; Huang, X.D.; Li, H.C.; He, S.; Ni, R.Z.; Chen, C.H.; Peng, C.; Wu, G.; Wang, G.H.; Wang, Y.Y. Expression of FOXJ1 in Hepatocellular Carcinoma: Correlation with Patients' Prognosis and Tumor Cell Proliferation. Mol. Carcinog. 2013, 52, 647-659. [CrossRef]

98. Peng, X.; Luo, Z.; Kang, Q.; Deng, D.; Wang, Q.; Peng, H.; Wang, S.; Wei, Z. FOXQ1 Mediates the Crosstalk between TGF- $\beta$ and Wnt Signaling Pathways in the Progression of Colorectal Cancer. Cancer Biol. Ther. 2015, 16, 1099-1109. [CrossRef] [PubMed]

99. Qiao, Y.; Jiang, X.; Lee, S.T.; Karuturi, R.M.; Hooi, S.C.; Yu, Q. FOXQ1 Regulates Epithelial-Mesenchymal Transition in Human Cancers. Cancer Res. 2011, 71, 3076-3086. [CrossRef]

100. Galli, L.M.; Barnes, T.; Cheng, T.; Acosta, L.; Anglade, A.; Willert, K.; Nusse, R.; Burrus, L.W. Differential Inhibition of Wnt-3a by Sfrp-1, Sfrp-2, and Sfrp-3. Dev. Dyn. 2006, 235, 681-690. [CrossRef]

101. Tago, K.; Nakamura, T.; Nishita, M.; Hyodo, J.; Nagai, S.; Murata, Y.; Adachi, S.; Ohwada, S.; Morishita, Y.; Shibuya, H.; et al. Inhibition of Wnt Signaling by ICAT, a Novel Beta-Catenin-Interacting Protein. Genes Dev. 2000, 14, 1741-1749.

102. Koon, H.B.; Ippolito, G.C.; Banham, A.H.; Tucker, P.W. FOXP1: A Potential Therapeutic Target in Cancer. Expert Opin. Ther. Targets 2007, 11, 955-965. [CrossRef] [PubMed]

103. Wolf, D.; Rodova, M.; Miska, E.A.; Calvet, J.P.; Kouzarides, T. Acetylation of $\beta$-Catenin by CREB-Binding Protein (CBP). J. Biol. Chem. 2002, 277, 25562-25567. [CrossRef]

104. Richter, G.; Gui, T.; Bourgeois, B.; Koyani, C.N.; Ulz, P.; Heitzer, E.; von Lewinski, D.; Burgering, B.M.; Malle, E.; Madl, T. $\beta$-Catenin Regulates FOXP2 Transcriptional Activity Via Multiple Binding Sites. FEBS J. 2020, 288, 3261-3284. [CrossRef] [PubMed]

105. Almeida, M.; Han, L.; Martin-Millan, M.; O’Brien, C.A.; Manolagas, S.C. Oxidative Stress Antagonizes Wnt Signaling in Osteoblast Precursors by Diverting Beta-Catenin from T Cell Factor- to Forkhead Box O-mediated Transcription. J. Biol. Chem. 2007, 282, 27298-27305. [CrossRef] [PubMed]

106. Essers, M.A.G.; de Vries-Smits, L.M.M.; Barker, N.; Polderman, P.E.; Burgering, B.M.T.; Korswagen, H.C. Functional Interaction Between $\beta$-Catenin and FOXO in Oxidative Stress Signaling. Science 2005, 308, 1181-1184. [CrossRef]

107. Hurlstone, A.; Clevers, H. T-Cell Factors: Turn-Ons and Turn-Offs. EMBO J. 2002, 21, 2303-2311. [CrossRef] [PubMed]

108. Carter, M.E.; Brunet, A. FOXO Transcription Factors. Curr. Biol. 2007, 17, R113-R114. [CrossRef]

109. Farhan, M.; Wang, H.; Gaur, U.; Little, P.J.; Xu, J.; Zheng, W. FOXO Signaling Pathways as Therapeutic Targets in Cancer. Int. J. Biol. Sci. 2017, 13, 815-827. [CrossRef] 
110. Tenbaum, S.P.; Ordóñez-Morán, P.; Puig, I.; Chicote, I.; Arqués, O.; Landolfi, S.; Fernández, Y.; Herance, J.R.; Gispert, J.D.; Mendizabal, L. $\beta$-Catenin Confers Resistance to PI3K and AKT Inhibitors and Subverts FOXO3a to Promote Metastasis in Colon Cancer. Nat. Med. 2012, 18, 892-901. [CrossRef]

111. Doumpas, N.; Lampart, F.; Robinson, M.D.; Lentini, A.; Nestor, C.E.; Cantù, C.; Basler, K. TCF/LEF Dependent and Independent Transcriptional Regulation of Wnt/ $\beta$-Catenin Target Genes. EMBO J. 2019, 38, e98873. [CrossRef] [PubMed]

112. Kong, X.; Zhai, J.; Yan, C.; Song, Y.; Wang, J.; Bai, X.; Brown, J.A.; Fang, Y. Recent Advances in Understanding FOXN3 in Breast Cancer, and Other Malignancies. Front. Oncol. 2019, 9, 234. [CrossRef] [PubMed]

113. Huang, C.; Ma, R.; Xu, Y.; Li, N.; Li, Z.; Yue, J.; Li, H.; Guo, Y.; Qi, D. Wnt2 Promotes Non-Small Cell Lung Cancer Progression by Activating WNT/ $\beta$-Catenin Pathway. Am. J. Cancer Res. 2015, 5, 1032-1046. [PubMed]

114. Yamamoto, H.; Oue, N.; Sato, A.; Hasegawa, Y.; Matsubara, A.; Yasui, W.; Kikuchi, A. Wnt5a Signaling Is Involved in the Aggressiveness of Prostate Cancer and Expression of Metalloproteinase. Oncogene 2010, 29, 2036-2046. [CrossRef] [PubMed]

115. Yoshioka, S.; King, M.L.; Ran, S.; Okuda, H.; MacLean, J.A.; McAsey, M.E.; Sugino, N.; Brard, L.; Watabe, K.; Hayashi, K. WNT7A Regulates Tumor Growth and Progression in Ovarian Cancer through the WNT/ $\beta$-Catenin Pathway. Mol. Cancer Res. 2012, 10, 469-482. [CrossRef] [PubMed]

116. Jung, Y.-S.; Jun, S.; Lee, S.H.; Sharma, A.; Park, J.-I. Wnt2 Complements Wnt/ $\beta$-Catenin Signaling in Colorectal Cancer. Oncotarget 2015, 6, 37257-37268. [CrossRef]

117. Klarmann, G.J.; Decker, A.; Farrar, W.L. Epigenetic Gene Silencing in the Wnt Pathway in Breast Cancer. Epigenetics 2008, 3, 59-63. [CrossRef]

118. Kaestner, K.H.; Schütz, G.; Monaghan, A.P. Expression of the Winged Helix Genes Fkh-4 and Fkh-5 Defines Domains in the Central Nervous System. Mech. Dev. 1996, 55, 221-230. [CrossRef]

119. Wang, T.; Zheng, L.; Wang, Q.; Hu, Y.-W. Emerging Roles and Mechanisms of FOXC2 in Cancer. Clin. Chim. Acta 2018, 479, 84-93 [CrossRef]

120. Cui, Y.; Jiao, H.; Ye, Y.; Chen, C.; Wang, J.; Tang, N.; Li, T.; Lin, J.; Qi, L.; Wu, P. FOXC2 Promotes Colorectal Cancer Metastasis by Directly Targeting MET. Oncogene 2015, 34, 4379-4390. [CrossRef]

121. Yang, D.; Li, Q.; Shang, R.; Yao, L.; Wu, L.; Zhang, M.; Zhang, L.; Xu, M.; Lu, Z.; Zhou, J.; et al. WNT4 Secreted by Tumor Tissues Promotes Tumor Progression in Colorectal Cancer by Activation of the Wnt/ $\beta$-Catenin Signalling Pathway. J. Exp. Clin. Cancer Res. 2020, 39, 251. [CrossRef]

122. Eichberger, T.; Regl, G.; Ikram, M.S.; Neill, G.W.; Philpott, M.P.; Aberger, F.; Frischauf, A.-M. FOXE1, a New Transcriptional Target of GLI2 Is Expressed in Human Epidermis and Basal Cell Carcinoma. J. Investig. Dermatol. 2004, 122, 1180-1187. [CrossRef] [PubMed]

123. Martynoga, B.; Morrison, H.; Price, D.J.; Mason, J.O. Foxg1 Is Required for Specification of Ventral Telencephalon and RegionSpecific Regulation of Dorsal Telencephalic Precursor Proliferation and Apoptosis. Dev. Biol. 2005, 283, 113-127. [CrossRef]

124. Diao, Y.; Rahman, M.F.U.; Vyatkin, Y.; Azatyan, A.; St. Laurent, G.; Kapranov, P.; Zaphiropoulos, P.G. Identification of Novel GLI1 Target Genes and Regulatory Circuits in Human Cancer Cells. Mol. Oncol. 2018, 12, 1718-1734. [CrossRef] [PubMed]

125. Cruciat, C.-M.; Niehrs, C. Secreted and Transmembrane Wnt Inhibitors and Activators. Cold Spring Harb. Perspect. Biol. 2013, 5, a015081. [CrossRef] [PubMed]

126. Kimura, H.; Sada, R.; Takada, N.; Harada, A.; Doki, Y.; Eguchi, H.; Yamamoto, H.; Kikuchi, A. The Dickkopf1 and FOXM1 Positive Feedback Loop Promotes Tumor Growth in Pancreatic and Esophageal Cancers. Oncogene 2021, 40, 4486-4502. [CrossRef]

127. Chen, F.; Xiong, W.; Dou, K.; Ran, Q. Knockdown of FOXK1 Suppresses Proliferation, Migration, and Invasion in Prostate Cancer Cells. Oncol. Res. Featur. Preclin. Clin. Cancer Ther. 2017, 25, 1261-1267. [CrossRef]

128. Nestal de Moraes, G.; Carneiro, L.d.T.; Maia, R.C.; Lam, E.W.-F.; Sharrocks, A.D. FOXK2 Transcription Factor and Its Emerging Roles in Cancer. Cancers 2019, 11, 393. [CrossRef]

129. Xie, R.; Wang, J.; Liu, X.; Wu, L.; Zhang, H.; Tang, W.; Li, Y.; Xiang, L.; Peng, Y.; Huang, X. RUFY3 Interaction with FOXK1 Promotes Invasion and Metastasis in Colorectal Cancer. Sci. Rep. 2017, 7, 1-11. [CrossRef]

130. Gao, C.; Chen, Y.-G. Dishevelled: The Hub of Wnt Signaling. Cell. Signal. 2010, 22, 717-727. [CrossRef] [PubMed]

131. Habas, R.; Dawid, I.B. Dishevelled and Wnt Signaling: Is the Nucleus the Final Frontier? J. Biol. 2005, 4, 22. [CrossRef]

132. Dubey, R.; van Kerkhof, P.; Jordens, I.; Malinauskas, T.; Pusapati, G.V.; McKenna, J.K.; Li, D.; Carette, J.E.; Ho, M.; Siebold, C. R-Spondins Engage Heparan Sulfate Proteoglycans to Potentiate WNT Signaling. eLife 2020, 9, e54469. [CrossRef] [PubMed]

133. Ertao, Z.; Jianhui, C.; Chuangqi, C.; Changjiang, Q.; Sile, C.; Yulong, H.; Shirong, C.; Hui, W. Low Level of FOXL1 Indicates a Worse Prognosis for Gastric Cancer Patients. Tumor Biol. 2016, 37, 11331-11337. [CrossRef] [PubMed]

134. Zhang, G.; He, P.; Gaedcke, J.; Ghadimi, B.M.; Ried, T.; Yfantis, H.G.; Lee, D.H.; Hanna, N.; Alexander, H.R.; Hussain, S.P. FOXL1, a Novel Candidate Tumor Suppressor, Inhibits Tumor Aggressiveness and Predicts Outcome in Human Pancreatic Cancer. Cancer Res. 2013, 73, 5416-5425. [CrossRef]

135. Herbst, A.; Jurinovic, V.; Krebs, S.; Thieme, S.E.; Blum, H.; Göke, B.; Kolligs, F.T. Comprehensive Analysis of $\beta$-Catenin Target Genes in Colorectal Carcinoma Cell Lines with Deregulated Wnt/ $\beta$-Catenin Signaling. BMC Genom. 2014, 15, 74. [CrossRef]

136. Christensen, J.; Bentz, S.; Sengstag, T.; Shastri, V.P.; Anderle, P. FOXQ1, a Novel Target of the Wnt Pathway and a New Marker for Activation of Wnt Signaling in Solid Tumors. PLoS ONE 2013, 8, e60051. 
137. Villacorte, M.; Suzuki, K.; Hirasawa, A.; Ohkawa, Y.; Suyama, M.; Maruyama, T.; Aoki, D.; Ogino, Y.; Miyagawa, S.; Terabayashi, T.; et al. $\beta$-Catenin Signaling Regulates Foxa2 Expression during Endometrial Hyperplasia Formation. Oncogene 2013, 32, $3477-3482$. [CrossRef]

138. Connelly, Z.M.; Yang, S.; Chen, F.; Yeh, Y.; Khater, N.; Jin, R.; Matusik, R.; Yu, X. Foxa2 Activates the Transcription of Androgen Receptor Target Genes in Castrate Resistant Prostatic Tumors. Am. J. Clin. Exp. Urol. 2018, 6, 172.

139. Li, Z.; Tuteja, G.; Schug, J.; Kaestner, K.H. Foxa1 and Foxa2 Are Essential for Sexual Dimorphism in Liver Cancer. Cell 2012, 148, 72-83. [CrossRef] [PubMed]

140. Balciunaite, G.; Keller, M.P.; Balciunaite, E.; Piali, L.; Zuklys, S.; Mathieu, Y.D.; Gill, J.; Boyd, R.; Sussman, D.J.; Holländer, G.A. Wnt Glycoproteins Regulate the Expression of Foxn1, the Gene Defective in Nude Mice. Nat. Immunol. 2002, 3, 1102-1108. [CrossRef]

141. Caron, A.; Xu, X.; Lin, X. Wnt/ $\beta$-Catenin Signaling Directly Regulates Foxj1 Expression and Ciliogenesis in Zebrafish Kupffer's Vesicle. Development 2012, 139, 514-524. [CrossRef]

142. Janssens, S.; Van Den Broek, O.; Davenport, I.R.; Akkers, R.C.; Liu, F.; Veenstra, G.J.C.; Hoppler, S.; Vleminckx, K.; Destrée, O The Wnt Signaling Mediator Tcf1 Is Required for Expression of Foxd3 during Xenopus Gastrulation. Int. J. Dev. Biol. 2013, 57, 49-54. [CrossRef] [PubMed]

143. Savage, J.; Voronova, A.; Mehta, V.; Sendi-Mukasa, F.; Skerjanc, I.S. Canonical Wnt Signaling Regulates Foxc1/2 Expression in P19 Cells. Differentiation 2010, 79, 31-40. [CrossRef]

144. Yeh, C.-H.; Bellon, M.; Nicot, C. FBXW7: A Critical Tumor Suppressor of Human Cancers. Mol. Cancer 2018, 17, 1-19. [CrossRef] [PubMed]

145. Larroux, C.; Luke, G.N.; Koopman, P.; Rokhsar, D.S.; Shimeld, S.M.; Degnan, B.M. Genesis and Expansion of Metazoan Transcription Factor Gene Classes. Mol. Biol. Evol. 2008, 25, 980-996. [CrossRef] [PubMed]

146. Schneider, S.Q.; Finnerty, J.R.; Martindale, M.Q. Protein Evolution: Structure-Function Relationships of the Oncogene Beta-Catenin in the Evolution of Multicellular Animals. J. Exp. Zool. Part. B. Mol. Dev. Evol. 2003, 295B, 25-44. [CrossRef]

147. Loh, K.M.; van Amerongen, R.; Nusse, R. Generating Cellular Diversity and Spatial Form: Wnt Signaling and the Evolution of Multicellular Animals. Dev. Cell 2016, 38, 643-655. [CrossRef]

148. Arqués, O.; Chicote, I.; Puig, I.; Tenbaum, S.P.; Argilés, G.; Dienstmann, R.; Fernández, N.; Caratù, G.; Matito, J.; Silberschmidt, D. Tankyrase Inhibition Blocks Wnt $\beta$-Catenin Pathway and Reverts Resistance to PI3K and AKT Inhibitors in the Treatment of Colorectal Cancer. Clin. Cancer Res. 2016, 22, 644-656. [CrossRef] [PubMed]

149. Shukla, S.; Milewski, D.; Pradhan, A.; Rama, N.; Rice, K.; Le, T.; Flick, M.J.; Vaz, S.; Zhao, X.; Setchell, K.D.; et al. The FOXM1 Inhibitor RCM-1 Decreases Carcinogenesis and Nuclear $\beta$-Catenin. Mol. Cancer Ther. 2019, 18, 1217-1229. [CrossRef]

150. Tang, Z.; Kang, B.; Li, C.; Chen, T.; Zhang, Z. GEPIA2: An Enhanced Web Server for Large-Scale Expression Profiling and Interactive Analysis. Nucleic Acids Res. 2019, 47, W556-W560. [CrossRef]

151. R Core Team. R: A Language and Environment for Statistical Computing; 4.1.0; R Foundation for Statistical Computing: Vienna, Austria, 2021. 